\title{
'Contrarius consensus':
}

terminación del contrato

por mutuo acuerdo en la

experiencia jurídica romana*

\section{Carlos Alberto Chinchilla ImbetT**}

Resumen: La terminación del contrato por mutuo acuerdo utilizada en el derecho contemporáneo no se puede encuadrar en los esquemas de la experiencia jurídica romana, donde nació como respuesta a la exigencia de terminación de los contratos consensuales mediante la aplicación de la correspondencia entre acto de constitución y extinción del vínculo negocial; así mismo, hacía referencia a un pacto ex intervallo cuya eficacia se encuadraba en los juicios de buena fe con límites en su empleo por la res integra; que permitía su aplicación de forma razonable y justa, así como garantizar a las partes el cumplimiento del fin por el cual celebraron el acuerdo resolutorio y evitar situaciones desventajosas para alguna de ellas.

Palabras clave: 'contrarius consensus', pactum, terminación del contrato, mutuo disenso, buena fe, derecho romano.

Este trabajo corresponde, con algunos ajustes, a la primera parte de la tesis desarrollada en la maestría en Sistema Jurídico Romanista, Unificación del Derecho y Derecho de la Integración del año académico 20I2-20I3 ofrecido por la Università degli studi di Roma 'Tor Vergata'.

Fecha de recepción: 7 de mayo de 20I4. Fecha de aceptación: 2 de marzo de 2015.

Para citar el artículo: C. A. Chinchilla Iмветт. “'Contrarius consensus': terminación del contrato por mutuo acuerdo en la experiencia jurídica romana”, Revista de Derecho Privado, Universidad Externado de Colombia, n. ${ }^{\circ}$ 28, enero-junio de 2015, pp. 79-I26. DOI: IO.1860I/or 234366. $\mathrm{N} 28.04$

** Magíster en Sistema Jurídico Romanista, Unificación del Derecho y Derecho de la Integración por la Università degli studi di Roma 'Tor Vergata', candidato a doctor en Derecho Civil por la Università degli studi di Genova, becario doctoral del Departamento de Derecho Civil de la Universidad Externado de Colombia, Colombia. Contacto: carlos.chinchilla@uexternado.edu.co 


\section{'Contrarius consensus': Termination of contract by mutual consent in Roman law}

Aвstract: Modern concept of termination of contract by mutual consent, used by civil tradition, can't match the Roman law experience. In the Roman law language, the 'contrarius consensus' was born in response to the demands of contractual consensual termination, through the correspondent application between the constitution and the extinction of contractual binding. Moreover, it referred to an agreement ex intervallo whose effectiveness is framed in good faith judgments with limits on its use by the res integra. This limit allowed its application with reasonability and fairness, in the sense that, the parties ensure the performance of their agreement and avoid unfavorable situations for either parties.

KEYwords. 'contrarius consensus', pactum, mutual termination of contract, good faith, Roman law.

Sumario: i. Premisa: los límites del consentimiento como mecanismo adecuado para dar lugar a la terminación del contrato II. El 'contrarius consensus': evolución y estructuración dogmática a partir del análisis de las fuentes del derecho romano. i. Las fuentes clásicas no usan términos unívocos para referirse al 'contrarius consensus'. 2. La simetría entre el acto constitutivo del vínculo jurídico y el acto extintivo del mismo constituye el fundamento dogmático e histórico del 'contrarius consensus'. 3. La naturaleza jurídica del 'contrarius consensus': pactum ex intervallo o contrarius actus determina los efectos resolutorios frente al contrato. 4. Los límites al 'contrarius consensus'. 5. De las otras formas de 'contrarius consensus'. 6. La esfera de aplicación del 'contrarius consensus' no se limitaba a la resolución del contrato de compraventa, sino que era aplicable a todos los contratos consensuales. 7. El 'contrarius consensus' en la compilación justinianea se ubica dentro del sistema de pactos del derecho romano, como una figura cuya aplicación estaba limitada a la exigibilidad de la res integra como garantía de coherencia del sistema.

\section{Premisa: los límites del consentimiento como mecanismo adecuado para dar lugar a la terminación del contrato}

El análisis de la tradición civil enseña que el contrato genera un vínculo entre las partes $^{\mathrm{I}}$, que debe ser respetado por ellas tal como lo ordena el principio general

I Se resalta el amplio estudio de la doctrina romanista que hace referencia al contractus y contrabere a fin de entender la creación del vínculo contractual entre las partes: cfr. P. Bonfante, Corso de diritto romano, Florencia, I900, 370; Id., Sul 'contractus' e sui 'pacta', en Scritti giuridici varii, III, Turín, I92 I, I33; G. Grosso, Il sistema romano dei contratti, Turín, I963, 29; Id., Contratto (diritto romano), en ED IX, Milán, I 989,750 ss. En el mismo sentido, sobre la importancia del vínculo 
de la buena $\mathrm{fe}^{2}$, lo que significa, en principio, que ni podrán evitarse los efectos propios del tipo contractual, ni terminarse con el vínculo que los sujeta o modificarse el contenido contractual unilateralmente 3 . No obstante, dicho vínculo no es indisoluble ni está creado para existir ilimitadamente, pues las partes bien pueden resolverlo de la misma forma como lo han creado, esto es, mediante su consentimiento. En este sentido, la posibilidad de disolver el vínculo por medio

en el derecho moderno, V. Roppo, Il contratto, Milán, 20 I I, 499; M. Bianca, Diritto civile, III, Il contratto, Milán, I987, 523 ss.

2 Aunque las partes están obligadas a cumplir con las obligaciones que emanan del contrato tal como lo ordena el principio general de la buena fe, esta sirve además como criterio normativo y de integración del vínculo negocial, el cual consiste en que el contenido de dicho vínculo no se limita simplemente a lo que hayan deseado las partes en su reglamento contractual, sino que comprende todo aquello que surja de las circunstancias concretas de la relación. En este sentido, la buena fe pasa de fundamentar la juridicidad del respeto a la palabra dada a enriquecer el contenido de las obligaciones típicas nacidas del contrato con deberes adicionales o adecuaciones de los deberes típicos o convencionalmente asumidos por las partes, coherentes con el modelo comportamental de honestidad y corrección exigido por la propia buena fe: cfr. R. Cardilli, 'Bona fides' tra storia e sistema, Turín, 20 Iо, 4I y Io I. En el mismo sentido y con referencia a la comunión de vida entre los hombres (societas vitae) se explica cómo desde el momento en que se concentra la atención en el vínculo jurídico que surge de los acuerdos entre los hombres de diferente ciudadanía se hace necesario indicar que el oportere que vincula y determina los efectos jurídicos del acuerdo es un oportere ex fide bona, esto es, se exige un comportamiento leal y correcto respecto de lo querido por las partes como de las circunstancias que determinan la relación: cfr. Id., Societas vitae, Cic. Off. 3.I7.70 e obligatio consensu contracta, en Bullettino dell'Istituto di Diritto romano 'Vittorio Scialoja', Milán, 20 I r, I94. En términos de F. Hinestrosa: "Buena fe, bona fides, fides... Concepto, principio, valor, que acá va más allá de la fidelidad o el respeto por la palabra empeñada; dijérase que desborda ese significado, para indicar un deber de comportamiento honesto, o mejor, un deber de honestidad en desarrollo del deber de colaboración": F. Hinestrosa, Leyendo el Digesto, en Roma e America. Diritto romano comune, 2 2, Roma, 2006, 70. Con ánimo de precisar, "la buena fe implica el respeto a la palabra empeñada, la escrupulosa y sincera observancia de las promesas y de los pactos, la veracidad y la constancia en los compromisos asumidos. En cuanto tal, está estrechamente ligada a la fidelidad a la palabra empeñada, y como se recordará se compendia en la constantia et veritas y en el fit quod dicitur a que alude Cicerón [de off. I.7.23]": M.L. NEME, La buena fe en el derecho romano. Extensión del deber de actuar conforme a buena fe en materia contractual, Bogotá, 2010, I63.

3 La importancia de respetar el vínculo contractual tiene una razón ética y otra funcional: la ética hace referencia a honrar las obligaciones asumidas, y la funcional hace alusión al contrato como un medio de organización de la vida económica y social, pues propende a que las partes cumplan sus acuerdos y no los desatiendan arbitrariamente. Adicionalmente, el vínculo está respaldado por el principio pacta sunt servanda, consistente en el imperativo moral de no traicionar el compromiso aceptado, de asumir la responsabilidad de las propias elecciones, de afrontar las consecuencias de sus decisiones. Las partes son libres de contratar o no contratar, pero en caso de que decidan celebrar un contrato se encontrarán vinculadas por los efectos del mismo. M.C. Cherubini, Degli effetti del contratto, en Dei contratti in generale, artt. 1350 e I386, en Commentario del codice civile, a cura di Enrico Gabrielli, Turín, 2008, 640; Roppo, Il contratto, cit., 500. En el mismo sentido y haciendo referencia a los efectos del negocio jurídico, "[s]e habla entonces de la naturaleza vinculante o compromisoria del negocio jurídico en sí y de por sí. Recorrida la definición, hay negocio jurídico, la conducta adquirió relevancia, tiene identidad y se expresa en la atadura de las partes o del único autor de la disposición, independientemente de la validez de ésta, como también de si sus efectos finales están diferidos y de si en últimas se producirán o no": F. Hinestrosa, Eficacia e ineficacia del contrato, en Revista de Derecho de la Universidad Católica de Valparaíso, Chile, I999, I46. 
de un posterior acuerdo de los contratantes no contradice el principio pacta sunt servanda, por el contrario, es una expresión de la autonomía contractual4, siempre y cuando se ejerza bajo los parámetros que la buena fe ordena5.

En efecto, el 'contrarius consensus' es la figura jurídica utilizada por la tradición civil para la resolución del vínculo contractual entre las partes, sin embargo, se debe tener en cuenta que la conceptualización del derecho contemporáneo del 'contrarius consensus' no es posible encuadrarla en los esquemas conceptuales dados por la experiencia jurídica romana ${ }^{6}$.

M. Franzoni, Mutuo dissenso, en Enc. Giur., Roma, 2004, i; P. Cecchi, L'efficacia del contratto, en I contratti in generale, viII, en Il diritto privato nella giurisprudenza, a cura di Paolo Cendon, Turín, I998, 4; G. De Nova, Il contratto ha forza di legge, en Scritti in onore di Rodolfo Sacco, II, Milán, I994, 339; Roppo, Il contratto, cit., 503; Bianca, Il contratto, cit., 700.

5 E. Betti, Teoria generale del negozio giuridico, Nápoles, 2002, IOI; A. D’Angelo, Il contratto in generale, Iv, La buona fede, en Tratatto di diritto privato, diretto da M. Bessone, xIII, Turín, 2004, 3; F. Hinestrosa, Función, límites y cargas de la autonomía privada, en Estudios de derecho privado, Universidad Externado de Colombia, Bogotá, I986, I 7.

6 P. Cerami, Risoluzione del contratto, diritto romano, en ED, XI, Milán, I989, I277. El 'contrarius consensus' es una figura a la que en las codificaciones modernas y en la doctrina en general se le asigna el nombre de mutuo disenso o resolución por mutuo consentimiento, caracterizándose por ser un instituto capaz de disolver el vínculo negocial y con una naturaleza estrictamente contractual: cfr. Cfr. A. Luminoso, Il mutuo dissenso, Milán, I980, 32 ss.; F. Ganzzoni, Obligazione e contratti, Nápoles, 2000, I008; F. GaLgano, Trattato di diritto civile, II, Milán, 2009, 477 ss.; Franzoni, Mutuo dissenso, cit., 2; Cecchi, L'efficacia del contratto, cit., i9; Cherubini, Degli effetti del contratto, cit., 643. Esta aproximación conceptual es el resultado de un devenir histórico en el que el rol de la autonomía privada ha sido determinante, puesto que durante los siglos XviII y XIX se amplió el poder que tenían las partes dentro de sus relaciones negociales para disponer de sus intereses, de manera que determinen el contenido contractual y los efectos queridos respecto a dicho contenido. De esta manera, las partes no se limitaron a producir obligaciones o modificarlas mediante acuerdo, sino también a extinguirlas. Cfr. BIANCA, Il contratto, cit., 317; Betтi, Teoria generale del negozio giuridico, cit., 52. Adicionalmente, en las codificaciones modernas de tradición romanista no existen límites a la aplicación de la figura resolutiva, como sí ocurría en la experiencia jurídica romana.

En el derecho actual la figura resolutoria está disciplinada bajo dos tipos de normas. Por un lado, las que regulan los efectos del contrato al disponer que el contrato tiene fuerza de ley, y por lo tanto, no puede ser disuelto salvo por mutuo consenso entre las partes o por aquellas causas admitidas por la ley; por otro, las que hacen referencia a la noción del contrato. Ejemplo de las primeras se encuentra en el artículo 1372 del Código Civil italiano en cuanto dispone: "Il contratto ha forza di legge tra le parti. Non puo essere sciolto che per mutuo consenso o per cause ammesse dalla legge". En el mismo sentido lo expresa el Código Civil francés en su artículo i I 34: "Les conventions légalement formées tiennent lieu de loi à ceux qui les ont faites. Elles ne peuvent être révoquées que de leur consentement mutuel, ou pour les causes que la loi autorise. Elles doivent être exécutées de bonne foi". En la experiencia de los códigos latinoamericanos se evidencia el ejemplo del modelo del Código Civil de Andrés Bello en el que se establece: "Todo contrato legalmente celebrado es una ley para los contratantes, y no puede ser invalidado sino por su consentimiento mutuo o por causas legales", modelo que fue tomado, entre otros, por el Código Civil de Colombia en el artículo r 602 y por el Código Civil de Chile en el artículo I 545. En el segundo caso de normas, se menciona el artículo I 32 I del Código Civil italiano que define al contrato como "l'accordo di due o più parti per costituire, regolare o estinguere tra loro un rapporto giuridico patrimoniale". Esta definición de contrato determina la preponderancia del acuerdo y la posibilidad que tienen las partes para celebrar uno que tenga como objeto la extinción de una relación contractual precedente. Esta concepción es adoptada por algunas legislaciones latinoamericanas, como es 
En el lenguaje del derecho romano, el término 'contrarius consensus' hacía referencia a un pacto: simple acuerdo de las partes dirigido a extinguir las obligaciones que nacen de los contratos consensuales ${ }^{7}$, cuya validez dependía de que dichos pactos no se hubieran celebrado dolosamente; ni contra la ley, los plebiscitos, senadoconsultos, los edictos y los decretos de los emperadores; ni mucho menos en fraude de las disposiciones normativas ${ }^{8}$. Además, la tutela jurídica de los pactos no era realizada por una actio sino mediante la exceptio pacti conventi 9 , que era el mecanismo de tutela típico de las figuras negociales que no producían obligaciones.

Dentro de la concepción romana, los pactos resolutorios del vínculo negocial no tenían naturaleza contractual porque no se encuadraban dentro de los tipos previstos en el sistema contractual esbozado por la experiencia jurídica romana ${ }^{\mathrm{IO}}$. Y su aplicación estaba específicamente limitada a la exigibilidad de la res integra ${ }^{\mathrm{I}}$ : el consentimiento de las partes consistente en la terminación del contrato no puede recaer sobre aquellos contratos en los que ya fueron ejecutadas sus prestaciones, pues permitir la disolución del contrato en ejecución genera eventos obligacionales posteriores a la celebración de la figura resolutoria y situaciones de desequilibrio entre las partes que la buena fe no tolera.

Así pues, la estructuración dogmática del 'contrarius consensus' desarrollada en la experiencia jurídica romana será el objeto del presente escrito, bajo la reflexión de las fuentes clásicas y la evidencia histórica de las instituciones, lo cual permitirá entender el verdadero alcance y la aplicación de la figura resolutoria ${ }^{\mathrm{I} 2}$.

\section{El 'contrarius consensus': evolución y estructuración dogmágtica a partir del análisis de las fuentes del derecho romano}

La estructura dogmática del 'contrarius consensus' en la experiencia del derecho romano está limitado por el número de fragmentos del Digesto que hacen refe-

el caso de Colombia en el artículo 864 del Código de Comercio, Venezuela en el artículo I I 33 del Código Civil y Perú en el artículo I35 I del Código Civil.

7 M. Talamanca, Istituzioni di diritto romano, Milán, i99o, 643; A. Burdese, Manuale di diritto privato romano, Turín, I993, 577 .

8 Cfr. D. 2.I4.7.7 Ulpianus Libro IV Ad Edictum; M. Talamanca, Istituzioni, cit., 6o6; Id., Contratto e patto nel diritto romano, en Estratto dal Digesto, Turín, I989, 37.

9 Cfr. D. 2.I4.7.4 Ulpianus Libro IV Ad Edictum; M. Talamanca, Istituzioni, cit., 6o6; A. Burdese, Manuale, cit., 487 .

Io G. Grosso, Il sistema romano dei contratti, cit., I 7 I ss.; Id., Il contratto (diritto romano), cit., 756; M. Talamanca, Contratto e patto nel diritto romano, cit., 32.

i I Cerami, Risoluzione del contratto, Diritto romano, cit., I 277.

I2 Es un instrumento aceptado para valorar y entender, en sentido crítico, las instituciones del derecho actual: cfr. M. BIANCA, Il diritto romano nella formazione del giurista, oggi: considerazioni di un civilista, en Il diritto romano nella formazione del giurista, oggi. Convegno organizzato dalla Facoltà di Giurisprudenza della seconda Università di Roma, Milán, I989, 43. 
rencia a la resolución consensual de contratos consensuales y por su acentuado carácter casuístico. Por ello se deberá acudir a un razonamiento intuitivo, al análisis de las interpolaciones y a las enseñanzas que deja la doctrina romanista que se ha encargado de estudiar la figura, para comprender los principios y las reglas que orientan y estructuran el 'contrarius consensus' dentro del ordenamiento jurídico romano.

\section{Las fuentes clásicas no usan términos unívocos para referirse al 'contrarius consensus'}

Con el fin de concretar el argumento histórico del 'contrarius consensus', se advierte que la terminología romana empleada, cuando se hace referencia a la resolución del contrato por mutuo acuerdo entre las partes contratantes, es variable ${ }^{\mathrm{I} 3}$, puesto que en los textos de los jurisconsultos romanos no se usa un único término técnico para indicar ese modo de resolución ${ }^{\mathrm{I} 4}$.

En efecto, se habla indiferentemente de la resolución como 'contrarius consensus' ${ }^{15}$, contraria voluntas ${ }^{16}$, dissensu ${ }^{17}$, así como de dissensu contrario ${ }^{18}$. En otro conjunto de fuentes se emplean los términos de abire, discedere, recedere ab emptio$n e$, entre otros ${ }^{19}$. No obstante, esta falta de designación de un término unívoco de la figura resolutoria no constituye una prueba en contra del carácter clásico del 'contrarius consensus', ni mucho menos un indicio de confusión o carencia de terminología técnico-jurídica para la disolución convencional de un negocio ${ }^{20}$. La diversidad terminológica se debe, por un lado, a la forma como la figura se desarrollaba en la praxis romana, pues existía una solución jurisprudencial consis-

I 3 R. Marini, Actus contrarius e pacisci nel contrarius consensus, tesis doctoral, Università degli Studi di Roma "Tor Vergata”, Roma, 20 Iо, I 2; P. Cerami, Risoluzione del contratto, Diritto romano, cit., I 279.

I4 G. Grosso, L'efficacia dei patti nei 'bonae fidei iudicia', en Scritti storico giuridici, III, Turín, 200 I [= en Studi Urbinati, I, I927, $3 \mathrm{I}]$.

I 5 D. 50.I7.35 Ulpianus Libro XLVIII ad Sabinum: “(...) ideo verborum obligatio verbia tollitur, nudi consensus obligatio contrario consensu dissolvitur".

I6 I. 3.29.4: "Hoc amplius eae obligationes, quae consensu contrabuntur, contraria voluntate dissolvuntur (...)"; C. 4.45.I: “(...) Etenim quod consensu contractum est, contrariae voluntatis adminiculo disolvitur (...)”.

I 7 D. I7.2.65 $\$$ 3. Paulus libro XXXII ad Edictum: “Diximud, dissensu solvi societatem (...)”. Para los jurisconsultos romanos el término de dissensus es polisémico. Es usado ya sea como aquella desarmonía o discordancia de las dos voluntades, o como un acto igual o contrario de consensus, el cual revela un acuerdo con miras a destruir un previo consenso contractual. Cfr. F. CANCELLI, Dissenso, profilo storico, en ED, XIII, Milán, I989, 235.

I 8 D. 46.3.80 Pomponius libro IV ad Quintum Mucium: "Quonuam consensu nudo contrabi potest, etiam dissensu contrario dissolvi potest".

I9 Sobre las fuentes clásicas que hacen referencia a los diferentes términos usados para referirse a la resolución del contrato convencional o contrarius consensus, ver: Cerami, Risoluzione del contratto, Diritto romano, cit., I 277 n.: 3, 4, IO, I I, I 2.

20 Marini, Actus contrarius e pacisci nel contrarius consensus, cit., I 3 . 
tente en la correspondencia entre la celebración del contrato y su terminación ${ }^{21}$, pero sin tener en cuenta la expresión usada en el caso particular ${ }^{22}$. Es decir que en diferentes supuestos de hecho, en los que se quería la terminación del negocio por mutuo consenso, se aplicaba la misma figura sin exigir un nombre fijo.

Por otro lado, se afirma que se debe al lenguaje jurídico romano usado en las fuentes, caracterizado por su riqueza de sinónimos y términos, razón por la cual no puede entenderse el derecho romano bajo la óptica de traducciones rígidas ${ }^{2}$. Por último, se sostiene, con menor eco, que una de las razones de la ausencia de univocidad en referencia al 'contrarius consensus' es la falta de una elaboración o reconocimiento sistemático de los modos de extinción de las obligaciones ${ }^{24}$.

Entonces, cualquiera que sea el término usado - resolvere y dissolvere, así como discedere, recedere, abire a-, es el 'contrarius consensus' el principal supuesto de hecho resolutivo al que hacían referencia los juristas clásicos y el consejo imperial, y que reconduce a la idea genérica de extinción de las obligaciones consensuales y a la remoción convencional del contrato con la respectiva neutralización de sus efectos.

\section{La simetría entre el acto constitutivo del vínculo jurídico y el acto extintivo del mismo constituye el fundamento dogmático e histórico del 'contrarius consensus'}

En la experiencia jurídica romana era claro y estaba interiorizado por los juristas que, así como se generaba un vínculo jurídico entre las partes, del mismo modo debía ser disuelto. Tanto es así que era una opinión difundida en la doctrina romanista que la regla que orientaba la disciplina de la extinción de las obligaciones en el derecho arcaico era el contrarius actus ${ }^{25}$. Este ordenaba que para

2 I Grosso, L'efficacia dei patti nei "bonae fidei iudicia", cit., 3; Cerami, Risoluzione del contratto, Diritto romano, cit., I 279 .

22 La resolución consensual del contrato surge como una forma más de extinción en respeto del principio de simetría. Lo que podría explicar que no se adptó un nombre técnico como particular modo de extinción, sino que se habla indiferentemente de contrarius consensus, contraria voluntas, consensus, etc., siempre y cuando se enuncie el principio sustancial. Cfr. Grosso, Il sistema romano dei contratti, cit., I08.

23 Cerami, Risoluzione del contratto, Diritto romano, cit., i 278 ; Marini, Actus contrarius e pacisci nel contrarius consensus, cit., I4.

24 Cfr. Cerami, Risoluzione del contratto, Diritto romano, cit., i 278 . En contra de este argumento, Marini, quien afirma que la razón por la cual existe multiplicidad de locuciones respecto al 'contrarius consensus' no puede descender de la ausencia de sistematizaciones y superestructuras teóricas puesto que es una práctica de la dogmática moderna y no romana. Cfr. MARINI, Actus contrarius e pacisci nel contrarius consensus, cit., I4. En el mismo sentido se sostiene que la ciencia jurídica romana no fue destinada a codificaciones coherentes y a unas concepciones generalizadas, como tampoco hubo necesidad de formas teóricas y técnicas con un léxico rigurosamente definido. Era el método casuístico, fundamentado en un ius controversium, el que se consideraba válido científicamente. Cfr. Talamanca, Istituzioni, cit., $5 \mathrm{ss}$.

25 Talamanca, Istituzioni, cit., 635 . 
eliminar una situación jurídica se debía usar una forma que tuviese correspondencia con aquella que le dio vida ${ }^{26}$. Tal regla está expresada en un fragmento del comentario ad Quintum Mucium de Pomponio en D. 46.3.80 ${ }^{[27]}$.

El fragmento sostiene que así como algo viene contractum, del mismo modo debe ser resuelto. Si se contrae $r e$, necesita resolverse $r e$, como por ejemplo en el mutuo, en el que se cumple restituyendo el tantundem eiusdem generis. Si se contrae verbis, el vínculo se disuelve re o verbis, que serían los casos de cumplir con la entrega de la cosa prometida o realizando una acceptilatio, respectivamente. Finalmente, si se contrae consensu, se puede resolver el vínculo también mediante 'consensu contrarius' 28 .

El fragmento corresponde a Q. Mucio (jurista republicano de finales del siglo ir e inicios del siglo III a.C.) pero es citado por Pomponio ${ }^{29}$, y en él se afirma la relación formal que debe existir entre la forma de celebración de determinados contratos y la de su terminación. No obstante, debido a la ausencia de una citación explícita del jurista republicano dentro del fragmento, se han hecho críticas sobre el carácter genuino del mismo. Una parte sostiene que D. 46.3.80 Pomponio IV ad Q. Mucium es de carácter clásico pero con eventuales intervenciones realizadas por Pomponio ${ }^{3 \circ}$. Otra, en cambio, afirma que el fragmento se

BuRdese, Manuale di diritto privato romano, cit., p. 576; Grosso, Il sistema romano dei contratti, cit. 107.

27 D. 46.3.80 Pomponio IV ad Q. Mucium: "Prout quidque contractum est, ita et solvi debet: ut, cum re contraxerimus, re solvi debet: veluti cum mutuum dedimus, ut retro pecuniae tantundem solvi debeat. Et cum verbis aliquid contraximus, vel re vel verbis obligatio solvi debet, verbis, veluti cum acceptum promissori fit, re, veluti cum solvit quod promisit. Aeque cum emptio vel venditio vel locatio contracta est, quoniam consensu nudo contrabi potest, etiam dissensu contrario dissolvi potest" ("De la manera que se contrató alguna cosa debe ser resuelto el contrato, de suerte que, cuando se haya contratado mediante una cosa, se debe pagar con la cosa, como, cuando hayamos dado en mutuo, se debe devolver otra tanta cantidad. Y cuando contratamos verbalmente alguna cosa, la obligación se debe disolver ó con la cosa, ó verbalmente; verbalmente, como cuando al promitente se le da por pagado[;] con la cosa, como cuando entrega lo que prometió. Igualmente, cuando se contrato compra, ó venta, o locación, como quiera que se pueden contratar por el nudo consentimiento, se pueden disolver también por el disentimiento contrario": trad. de D.I. García del Corral, Cuerpo del Derecho Civil Romano, Digesto, III, Barcelona, I889, 613).

28 R. Frori, Contrahere e solvere obligationem in Q. Mucio Scevola, en Fides Humanitas Ius. Studi in onore di Luigi Labruna, Nápoles, 2007, $195^{8}$.

29 P. Voci, La dottrina romana del contratto, Milán, I946, 80; F. GALlo, Synallagma e conventio nel contratto, Ricerca degli archetipi della categoria contrattuale e spunti per la revisione di impostazioni moderne. Corso di Diritto romano, I, Turín, I992, 25 ; Talamanca, Istituzioni, cit., 635; C. Cascione, Consensus, problema di origine, tutela processuale, prospettive sistematiche, Nápoles, 2003, 408 y 4 Io.

Cfr. C.A. Cannata, La 'distinctio' re-verbis-litteris-consensu et les problèmes de la pratique (Études sur les obligations I), en Sein und Werden im Recht. Festgabe U. von Lübtow, Berlín, I970, 442 ss. Para justificar esta diferencia en el fragmento, y afirmando que el fragmento es unívocamente enunciado por Q. Mucio sin la intervención de Pomponio, F. Gallo explica que el pasaje se articula en dos partes: una basada sobre el principio de la exigibilidad (debet) de correspondencia entre el modo de contrabere y de solvere, y una segunda parte en la que tal principio se reducía a términos de posibilidad (potest); cfr. F. Gallo, Synallagma e conventio nel contratto, I, cit., 28. 
encuentra alterado por los compiladores justinianeos ${ }^{3 \mathrm{I}}$. Sin embargo, ninguna de las tesis parece correcta ${ }^{32}$.

Si se analizan los orígenes de las instituciones de la experiencia jurídica romana, se percibe de manera más acentuada la relación formal entre el acto constitutivo y extintivo de las relaciones negociales expresada en el fragmento, toda

3 I La crítica interpolacionista evidencia una contradicción entre la afirmación general con la cual se abre el discurso muciano y la ejemplificación. Aunque parece ser concordante respecto a la obligatio re y consensu contractae, esto no sucede con la verbis, puesto que da por sentado que la obligación contractual verbis pueda extinguirse vel re, vel verbis: re, con el pago de lo que fue prometido, y verbis, con la acceptilatio. Lo anterior trae como consecuencia que dentro del fragmento se afirme, por una parte, que el principio formal de correspondencia no está planteado en términos de necesidad, y por la otra, el efecto liberatorio de ambas figuras, esto es, del cumplimiento y del acto formal, respecto a la obligatio verbis. Cfr. Voci, La dottrina romana del contratto, cit., 80 n. 2.; S. Solazzi, L'estinzione dell'obbligazione nel diritto romano, I, Nápoles, 1935, I6; Grosso, Il sistema romano dei contratti, cit., ro9. Adicionalmente, se sostiene que las enunciaciones generales, como la expresión prout quidque contractum est, ita et disolvi debet, representan la manía de sistematizar y generalizar por parte de los bizantinos. Cfr. Grosso, Il sistema romano dei contratti, cit., I07.

32 Se comparte la argumentación de Fioni, quien sostiene que las contradicciones en el texto podrían desvanecerse siempre y cuando se haga una lectura renovada del fragmento. Para ello, téngase en cuenta la colocación palingenésica del fragmento -situado en la liberatio legata, o sea del legado con el cual se dispone la liberación del legatario por una deuda-, que permite entender que el interés definitorio de Q. Mucio no se dirigía principalmente al contrabere, sino al solvere obligationem. Es decir, el discurso muciano parte del problema de la remisión de la deuda, y por ello la regla a aplicar sería la de la correspondencia entre la forma de contrahere y la forma de solvere obligationem, pero bajo el análisis del verbo solvere, puesto que debido a la ubicación del fragmento, la institución a analizar era una remisión. Diferente sería la reflexión si se hiciera a partir de la centralidad del contrahere, ya que en tal caso sería necesario ver la simetría del tipo contractual con la forma de extinción, por ejemplo, contraherere 'solvere re, lo cual no se encuentra y por lo tanto conduce a suponer intervenciones compilatorias.

En ese orden de ideas, Fiori precisa la centralidad del verbo solvere en el fragmento, lo que permitiría entender el discurso muciano. Entonces, el presupuesto es el valor de la expresión solutio pues, en ese momento histórico, significaba la genérica extinción de la obligación, sea por remisión o sea por pago. Luego, Q. Mucio parte de las obligationes re contractae, para indicar que es el solvere re el que disuelve al contrahere re, y pone como ejemplo el cumplimiento en el mutuo, en el cual se da una cosa ut retroque pecuniae tantundem solvit debeat. Posteriormente, la categoría a tener en cuenta en el fragmento es la de las obligationes verbis contractae, y la regla de la simetría hace referencia a la remisión de la deuda mediante una acceptilatio. Pero se añade que, en el plano del cumplimiento, se puede también solvere re, cum solvit quod promisit, es decir, es posible cumplir ya sea mediante la entrega de una cosa como también mediante comportamientos no verbales -esto último en concordancia con los conceptos con los que LABEón describía el gestum como res sine verbis facta y el actum como comportamiento realizado sive verbis re en D. 50.16.19 Ulpianus XI ad Edictum. Los ejemplos del actum son la stipulatio y la numeratio, o sea un contrato verbal y otro real, pero el recuerdo del gestum parecería referirse a que con agere $r e$ se indicaban todas las actividades que no son verbales. Es de recordar nuevamente que para el momento histórico de Q. Mucio, el cumplimiento tenía la fuerza para extinguir el vínculo generado por una obligatio verbis contracta, y la acceptilatio, como actus contrarius, hacía referencia a las hipótesis de remisión. Finalmente, Fiori se refiere a los contratos consensuales, y escribe que la relación contractual surge sobre la base del simple consenso, por ello la obligación puede ser extinguida también mediante el dissensus. Acá el verbo acompañante al solvere es un potest, puesto que junto a la solutio del cumplimiento existe una solutio representada por el acuerdo contrario: la obligación puede ser extinguida sea con el dissensus sea con el cumplimiento. Cfr. Fiori, Contrahere e solvere obligationem in Q. Mucio Scevola, cit., I970 ss. 
vez que se encuentra una forma paralela y proporcional de resolución según la lógica de la correspondencia entre constitución y extinción 33 inspirada en los ritmos naturales de la vida misma, cuya interpretación se hacía en las primitivas comunidades por medio de los pontífices, quienes sabían crearse un rol y una autoridad para así conectar los comportamientos permanentes y significativos para la sociedad con aquella ritualidad arcaica, y que luego convertían en reglas de conducta 34 .

En efecto, el 'contrarius consensus' nace como respuesta a la exigencia de dar por terminados los contratos consensuales por el mutuo acuerdo de las partes y bajo el respeto de los principios de la praxis romana. Por el hecho de que los contratos consensuales surgieran en el ámbito del comercio internacional, el tráfico no les permitía ser simplemente considerados como contratos de ejecución inmediata sino como de ejecución futura, y por eso, entre el momento de su celebración y ejecución, podían cambiar las circunstancias, de modo que las partes desearan darlo por terminado. Así por ejemplo, en el caso de la compraventa, su función no consistía en el mero cambio de cosa por precio, sino también en el acuerdo de hacer en el futuro un intercambio que a las partes no les convenía ejecutar en el momento de la celebración del contrato; y era por lo tanto probable que los supuestos de hecho con base en los cuales el vendedor o el comprador habían convenido una emptio venditio cambiasen, y en consecuencia surgiese el deseo mutuo de dar por terminado el contrato anteriormente celebrado ${ }^{35}$, para lo cual se debía usar la figura que sirviese para tales fines sin violar la regla de simetría.

Junto a lo anterior, y en aras de entender el sentido del fragmento, se recuerda que la obligación arcaica no se extinguía como efecto directo del cumplimiento de las obligaciones a cargo del deudor, sino que era necesaria la intervención de un acto idéntico en la forma al que había creado la obligación, y dirigido a extinguirla ${ }^{3}$. Era en un momento posterior, cuando se reconocía que el pago

Grosso, L'efficacia dei patti nei 'bonae fidei iudicia', cit., 3; Id., Il sistema romano dei contratti, cit., I07.

34 Al respecto se pone el ejemplo de la época arcaica -en la que lo divino y lo humano se confundíanconsistente en la adquisición de la manus maritalis farreo por medio de la confarreatio: ceremonia religiosa durante la cual, después de haber pronunciado aquellas fórmulas rituales, los recién casados ofrecían en sacrificio a Iupiter Farreus un pan de cereales. En correspondencia con la llamada regla de simetría, el modo de disolución del matrimonio confarreatio era mediante la diffarreatio, acto sacro contrario elaborado por los pontefices en el que se daba por terminados los efectos de la manus y consecuentemente la mujer volvía a su anterior condición. MarinI, Actus contrarius e pacisci nel contrarius consensus, cit., I 7. Adicionalmente, se atestigua que para la edad arcaica, la obligación nacida por gestum per aes et libram debía extinguirse con el gestum contrario: solutio per aes et libram; así mismo la obligación nacida verbis por medio de la sponsio mediante pregunta y respuesta debía extinguirse con los verba contraria de la acceptilatio. Cfr. Burdese, Manuale di Diritto Privato Romano, cit., 576.

35 A. Guarino, Per la storia del 'contrarius consensus', en Labeo, Napolés, I 968, 278 ss.

36 M. Talamanca, Istituzioni, cit., 642. 
-puro y simple- era causa suficiente para la extinción de las obligaciones, es decir, el cumplimiento per se encontraba su eficacia liberatoria, lo que conducía a prescindir de una forma que lo acompañara para generar los efectos extintivos.

$\mathrm{Y}$ todo esto tiene que ver con el papel preponderante que tenía el verbo solvere en la experiencia jurídica romana. Solvere, según el valor etimológico, indicaba la liberación del vínculo (solvere es la antítesis de ligare) ${ }^{37}$, pero el alcance se determinaba según el momento histórico. Entonces, en un primer momento, en el que el cumplimiento no tenía la fuerza extintiva de la obligación, la liberación era material y necesitaba acompañarse del acto contrario para generar los efectos liberatorios queridos. En un segundo momento, el significado se ampliaba y permitía que el objeto de la liberación ya no fuese el deudor sino la prestación a la cual se había comprometido ${ }^{3}$. En ese orden de ideas, el solvere adquiría un doble valor, ya fuese como la ejecución del contenido obligatorio o como la eliminación del vínculo por actus contrarius ${ }^{39}$.

En este sentido, la fuerza extintiva per se del cumplimiento trae como consecuencia que el contrarius actus sea aplicable bajo el entendido de que la obligatio pueda extinguirse, en lugar del cumplimiento, por un acto contrario que se caracteriza por su causa liberatoria mas no satisfactoria del acreedor $4^{\circ}$. De ahí que, una vez reconocida la fuerza obligatoria de los contratos fundados en el mero consenso, sin formalismo alguno, era natural que la ejecución de las obligaciones nacidas del contrato pudiese resolver el vínculo, y que, en aquellos casos en los que se quisiese la resolución sin ejecución de las prestaciones, el mero consentimiento de las partes fuese válido para eliminar el fundamento del vínculo contractual4 ${ }^{\mathrm{I}}$.

Todo lo dicho permite afirmar, luego del análisis del testimonio muciano de la jurisprudencia del siglo in a.C., que se consagra el contrarius actus como regla general, y que dentro de ella existen figuras heterogéneas como la acceptilatio, la solutio pecuniae respecto del mutuo y, por supuesto, el 'contrarius consensus' 42 . Este

\section{S. Solazzi, L'estinzione dell'obbligazione nel diritto romano, cit., 9.}

B. Periñán, Pomponio y la clasificación de los modos de extinción de las obligaciones, en Iura, LiI, Nápoles, 200 I, I95 ss.; Talamanca, Istitutioni, cit., 635.

S. Solazzi, L'estinzione dell'obbligazione nel diritto romano, cit., I 3 y i 9.

Burdese, Manuale di Diritto Privato Romano, cit., 576.

Grosso, L'efficacia dei patti nei 'bonae fidei iudicia', cit., 4.

Otro fragmento de las fuentes romanas que confirma la resolución de la obligatio consensu contractae por medio de otro consensu contrario, es un comentario redactado por ULPIANo -jurisconsulto de la época de los Severos-, a los libri iuris civilis de Sabino D. 50.I7.35: "Nibil tam naturale est, qua meo genere quidque dissolvere, quo colligatum est; ideo verborum obligatio verbis tollitur, nudi consensus obligatio contrario consensu dissolvitur". El texto en cuestión, en su parte inicial hace referencia a la denominada regla de simetría y expresa que es natural extinguir las relaciones negociales de la misma forma como se contrató, y concretamente, expone que la forma de extinción de la obligatio verbis es mediante las palabras y en lo que corresponde a la obligatio consensu contractae, por surgir mediante el simple consensus, lo natural es su disolución 
último, como la figura que nace de la necesidad de extinguir la relación contractual, pero a partir de la disolución del vínculo de los contratos consensuales sin considerar el cumplimiento, pago o cualquier otro formalismo, y sí sobre la base del paralelismo entre el acto constitutivo y el acto extintivo de la relación negocial. Es decir, que sea un consensus caracterizado por sus efectos extintivos el llamado a dar por terminado el vínculo de la obligatio consensus contractae, todo esto en respeto a los principios y reglas que orientan la praxis contractual, que en este caso es la regla de simetría.

\section{La naturaleza jurídica del 'contrarius consensus': 'pactum ex intervallo' o 'contrarius actus' determina los efectos resolutorios frente al contrato}

Sobre la naturaleza jurídica del 'contrarius consensus' la doctrina ${ }^{43}$, con base en el análisis de fragmentos de la jurisprudencia clásica compilados en el Digesto, se ha cuestionado si este instituto fue construido por los romanos como una figura propia del ius civile, específicamente como un negocio de disolución del contrato consensual44, o si fue concebido como un pacto entre las partes de un contrato consensual cuyo objeto era la eliminación del contrato celebrado precedentemente, y su eficacia se encontraba en la inherencia de la exceptio pacti a los bonae fidei iudicia ${ }^{45}$.

Esta discusión parte del análisis, en particular, de un fragmento del comentario de Paulo al Edicto, D. I 8.5.3 Paulus Libro XXXIII ad Edictum ${ }^{46}$, en el cual se

por el 'contrarius consensus'. Con el fragmento se quiere indicar que existe una regla natural genérica en la que encajan diferentes modos de extinción del vínculo por ser compatibles con la regla. Uno de estos modos sería el 'contrarius consensus' frente al contrato consensual, en el sentido de darle la posibilidad de resolverlo, como expresión de la relación natural que existe entre el modo de contraer el vínculo y el modo de extinguirlo. Sobre el particular: F. GaLLo, Synallagma e conventio nel contratto, I, cit., 35. Grosso, Il sistema romano dei contratti, cit., Io8; Marini, Actus contrarius e pacisci nel contrarius consensus, cit., 27.

43 Sobre el particular: Guarino, Per la storia del 'contrarius consensus', cit., 27 I ss.; G. Grosso, Recensione a Rolf Knütel, Contrarius consensus, Studien zur Vertragsanfhebung im romischen Recht, en Studia et Documenta Historiae et Iuris, 34, I968, 403-410; Id., L'efficacia dei patti nei 'bonae fidei iudicia', cit., I ss.; Id., Il sistema romano dei contratti, cit., Io6 ss., I 56 ss., I 7 I ss.; A. BuRDESE, Recensione a Rolf KnüTel, Contrarius consensus, Studien zur Vertragsanfhebung im romischen Recht, en Index, 2, Nápoles, I97 I , 342; G. Gandolfi, Recensioni critiche a Knütel, R., Contrarius consensus, Studien zur Vertragsaufhebung im römischem Recht, en Iura, 20, Nápoles, I969, 599 ss.; B. BionDI, Iudicia bonae fidei, en Annali del Seminario Giuridico, Università di Palermo, viı, Palermo, i9 18; Cerami, Risoluzione del contratto, Diritto romano, cit., i 278 ss.; Marini, Actus contrarius e pacisci nel contrarius consensus, cit., 47 ss.

44 En especial D. 46.3.80 Pomponius libro IV ad Quintum Mucium; I. 3.29.4; D. I 8.5.3 Paulus Libro XXXIII ad Edictum.

45 D. 2.I4.7 $\$$ 5-6 Ulpianus libro IV ad Edictum; D. I 8.5.3 Paulus Libro XXXIII ad Edictum.

46 D. I 8.5.3 Paulus Libro XXXIII ad Edictum: "Emptio et venditio sicut consensu contrabitur, ita contrario consensu resolvitur, antequam fuerit res secuta: ideoque quaesitum est, si emptor fideiussorem acceperit vel venditor stipulatus fuerit, an nuda voluntate resolvatur obligatio. Iulianus scripsit ex empto quidem agi non posse, quia bonae fidei iudicio exceptiones pacti insunt: an autem fideiussori utilitis sit exceptio, videndum: et puto liberato reo et fideiussorem liberari. item venditorem ex stipulatu agentem exceptione summoveri 
manifiesta que la compraventa puede ser resuelta por el consentimiento contrario siempre y cuando no se haya ejecutado ninguna de las obligaciones nacidas del contrato, es decir, que se mantenga la res integra. Posteriormente, el jurista se cuestiona sobre aquellos casos en los que se resuelve el contrato por 'contrarius consensus' y el comprador hubiera aceptado un fiador, o en los que el vendedor hubiera deducido el crédito del precio con base en una estipulación. Sobre el particular, Paulo llama la atención sobre una opinión de Juliano donde afirma que el comprador no puede ejercer la acción de compra contra el vendedor, puesto que al hacerlo le será opuesta por este último la excepción propia del pacto resolutorio, el cual es inherente a iudicia bonae fidei. En caso de que operara contra el fiador, se debe saber si este obtiene las ventajas de la excepción. En cambio, Paulo considera que, liberado el deudor por 'contrarius consensus', también lo es el fiador, y por ello, en aquellos casos en los que el vendedor reclama en virtud de la estipulación, deberá ser repelido con una excepción, y lo mismo sucederá con el comprador que reclame contra el fiador.

Existen tres teorías en las que se intenta esbozar la reconstrucción de la naturaleza jurídica del 'contrarius consensus' con base en el fragmento47: (i) por una parte, Grosso y Siber sostienen que la configuración del 'contrarius consensus' como actus contrarius del contrato consensual fue típica y exclusiva del derecho romano clásico. Los compiladores justinianeos fijaron el 'contrarius consensus' como un pactum ex intervallo y configuraron su eficacia extintiva ipso iure como consecuencia del principio pacta conventa inesse bonae fidei iudiciis. (ii) Por otra, Stoll considera que en el derecho clásico faltaba una concepción unitaria y general del 'contrarius consensus'. En materia de emptio venditio se usaba un pactum ut habeatur -pacto resolutorio- con eficacia procesal directa e inmediata, y con el límite de que las prestaciones del contrato no se hubieran ejecutado, en virtud de la inherencia del pacto a los iudicium bonae fidei. En derecho posclásico, el pactum ut habeatur era considerado aplicable a todos los contratos consensuales y pasaba a ser encuadrado como un 'contrarius consensus' en la figura del actus contrarius. (iii) Por último, KNüTEL sostiene que existía una divergencia de opiniones entre los juristas romanos: Juliano habría concebido explícitamente al 'contrarius consensus' como simple pactum pretorio, cuya eficacia extintiva ipso iure

oportet, idemque iuris ese, si emptor quoque rem in stipulationem deduxerit" ("La compra y venta, así como se verifica por el consentimiento, así se disuelve por contrario consentimiento, antes que el negocio se haya consumado. Y por esto se preguntó, si el comprador hubiere recibido fiador, ó el vendedor hubiere estipulado, si se disolverá la obligación por la nuda voluntad. Escribió Juliano, que ciertamente no puede ejercitarse la acción de compra, porque las excepciones del pacto se hallan comprendidas en el juicio de buena fe; pero se ha de ver, si tendrá el fiador la excepción útil. Y opino, que hecho libre el deudor, también el fiador se hace libre; que asimismo debe ser repelido con excepción el vendedor que reclama en virtud de lo estipulado; y que el mismo derecho hay, si el comprador hubiere comprendido también la cosa en la estipulación: trad. de D.I. García Del Corral, Cuerpo del Derecho Civil Romano, Digesto, I, cit., 920).

47 Para ver esta reconstrucción se recomienda consultar: GuARINo, Per la storia del 'contrarius consensus', cit., 272; Cerami, Risoluzione del contratto, Diritto romano, cit., i 280. 
estaría apoyada en la inherencia de la exceptio pacti a los bonae fidei iudicia. PAulo, en cambio, lo entendía como un negocio civil de resolución, lo configuraba como autónomo y con eficacia en el plano del ius civile y por fuera de los iudicium bonae fide $i^{4}{ }^{8}$. El autor llega a esta conclusión por la evidente diferencia de los efectos del 'contrarius consensus' sobre las garantías -fiador y la estipulación-: Juliano no le atribuía efectos extintivos inmediatos y Paulo, por el contrario, sí lo hacía al expresar que, liberado el deudor, también lo sería el fiador, liberato reo et fideiussorem liberari49.

Estas líneas argumentativas trabajan sobre la idea de que el fragmento no es genuino en su formulación, y en el desarrollo exegético ponen de relieve las interpolaciones tanto de estilo ${ }^{50}$ como sistemáticas $^{5}{ }^{\mathrm{I}}$. No obstante, tales sospechas

48 G. Gandolfi, Recensioni critiche a Knütel, R., Contrarius consensus, cit., 6oo; Grosso, Recensione a Rolf Knütel, Contrarius consensus, cit., 407; Burdese, Recensione a Rolf Knütel, Contrarius consensus, cit., 343.

49 Según KNüTel, la conceptualización de PAulo sería aislada, extraña y no aplicada por los romanos, en el entendido de que la concepción interiorizada sería la explicada por Juliano en la que se explica el 'contrarius consensus' como un pactum. Ver G. Grosso, Recensione a Rolf Knütel, Contrarius consensus, cit., 406. La tesis de Paulo encontraría confirmación en fragmentos escritos por él: D. 2.I4.27\$2 Paulus III ad Edictum; D. 4.2.2 I $\$ 4$ Paulus XI ad Edictum; D. 4I.2.8 Paulus LXV ad Edictum y D. 50.I 7.53 Paulus LXV ad Edictum. Se trataría de una tesis típica del pensamiento escolástico tardío-clásico y especialmente paulino. Se afirma que no se encuentran citas de la tesis de Paulo en fragmentos de otros juristas, pero sí lo recogerían los bizantinos siguiendo la línea del fragmento de las Istitutas Iustineanei 3.29.4. Ver Burdese, Recensioni a Rolf Knütel, Contrarius consensus, cit., 342. Es evidente que Paulo no se dejaba condicionar por los vínculos dogmáticos en aquellas soluciones de orden sustancial que según él debían ser adoptadas. Ver G. Gandolfi, Recensioni critiche a Knütel, R., Contrarius consensus, cit., 6oo. Por otra parte se menciona que el mayor mérito de Knütel es haber infringido el rígido bipolarismo de las reconstrucciones, ya sea el 'contrarius consensus' un pactum o un actum, para luego intuir que desde la época clásica convivían dos diferentes argumentaciones reconstructivas sobre el 'contrarius consensus' encarnadas en PAULO y Juliano. Ver Marini, Actus contrarius e pacisci nel contrarius consensus, cit., 64.

50 Se afirma que ha sido intervenido el fragmento por los compiladores justinianeos debido a la incoherencia que presenta el discurso del jurista al tratar temas diferentes: la afirmación de la res integra como requisito fundamental para la eficacia del 'contrarius consensus' nada tiene que ver con el razonamiento y el papel central que juega la obligatio del fiador-garante: Grosso, L'efficacia dei patti nei 'bonae fidei iudicia', cit., I 3 ss., y MARINI, Actus contrarius e pacisci nel contrarius consensus, cit., 39. No se comparte tal afirmación pues no se evidencia incongruencia alguna: la primera de las razones es que el problema central del fragmento no se refiere a la res integra sino a los efectos que tiene el 'contrarius consensus' en las garantías que refuerzan una de las obligaciones de la compraventa. La segunda de ellas es que la inclusión de la res integra tiene una razón de ser: es el requisito que siempre era exigible para la aplicación de la figura resolutoria, pues permitir la aplicación del 'contrarius consensus' con las prestaciones ejecutadas habría permitido que de un pacto se generara una acción, lo cual era imposible en la mentalidad romana. Estas razones fundamentadas en la construcción palingenésica las realiza O. Lenel, Palingenesia iuris civilis. Volumen prius, Austria, Akademische Druck- und Verlagsanstalt, I960, I034: el autor plantea la hipótesis consistente en que entre los $\$ \$$ I y 2 del actual orden de D. I 8.5.5 debería encontrarse el parecer de JuLIANo citado por Paulo en D. I8.5.3, pues en D. I8.5.5 hace referencia a los efectos del 'contrarius consensus' frente al contrato. Lo cual parece razonable, ya que el verdadero sentido del parecer de JuLiano se relaciona con la eficacia del 'contrarius consensus' sobre las garantías del contrato: simplemente los compiladores decidieron ubicarlo en D. I 8.5.3 con el fin de construir una hipótesis diferente respecto a la res integra. Cfr. R. CARDILLI, Iulianus XV Digestorum (D. I 8,5,5,I-2) e limiti al contrarius consensus, en Festschrift für Rolf Knütel zum 7o. Geburtstag, Heidelberg, C.F. Müller Verlag, I49.

Se asevera que aquellos fragmentos en los que se considera la aplicación del 'contrarius consensus' 
parecen simple reflejo de una lectura apasionada del fragmento con el fin de justificar la interpretación que se haya elaborado ${ }^{52}$. Por ello, realizar una renovada

en concordancia con el principio de la inherencia de la exceptio pacti a los iudicia bonae fidei son interpolados, bajo dos teorías: (i) SToll afirma que la eficacia del pacto de resolución habría sido sustancialmente procesal al ocurrir exceptio pacti; en tal sentido, el principio había sido para los clásicos tan natural en su aplicación que no había necesidad de expresarlo. Habrían sido los compiladores los encargados de introducirlo en las fuentes clásicas y por lo tanto de dotarlo de efectos ipso iure. Así pues, aunque se afirma interpolada la parte de la inherencia de los pactos a los juicios de buena fe, el principio era clásico (H. S Toll, Die formolose Vereinbarung der Aufhebug eines Vertragsverbältnisses im römischen Recht, cit. por Grosso, L'efficacia dei patti nei 'bonae fidei iudicia', cit., 7); (ii) Grosso sostiene que tal principio era completamente desconocido por los clásicos, y que la inserción del principio de inherencia se debió a los compiladores. Si los clásicos no conocían que la exceptio pacti, que emana del pactum de non petendo, era inherente a los bonae fidei iudicia, mucho menos conocían el principio general de los pacta conventa inesse bonae fidei iudiciis, en virtud del cual los pactos entre las partes tenían eficacia directa porque operaban sobre el oportere ex fide bona. Se afirma que el 'contrarius consensus' era completamente autónomo y que su operatividad era iure civile; solo una obra de nivelación posclásica o bizantina sobre la base de la fides bona absorbería tal autonomía y lo incluiría en un principio más general, esto es, la exceptio pacti inest bonae fidei iudicis. Ver Grosso, L'efficacia dei patti nei 'bonae fidei iudicia', cit., I 3 ss. No obstante esta línea argumentativa, parece más convincente aquella teoría que afirma que para los clásicos cualquier pacto, sea in continenti o ex intervallo, tenía en los iudicia bonae fidei plena eficacia sin necesidad alguna de exceptio. La buena fe, que era el criterio directivo de todo el juicio, imponía al juez que tuviera en cuenta aquellos pactos realizados entre las partes; el conocimiento de los pacta por parte del juez hacía que él quedara investido en virtud del oportere ex fide bona, independientemente de la inserción en la fórmula de una particular exceptio, es decir, la exceptio pacti se inserta a los bonae fidei iudicia, por lo cual no era necesario indicar explícita y adecuadamente en la fórmula el requerimiento del pacto celebrado por las partes cuando este es modificatorio del contenido originario de la obligación. Ver B. BIONDI, Iudicia bonae fidei, cit., 23. Todo fundamentado en los fragmentos clásicos de D. I 8.5.3 Paulus Libro XXXIII ad Edictum; D. 2.14.7 \$6 Ulpianus libro IV. Ad Edictum, y D. 2.I4.58 Neratius libro III. Membranarum.

52 Sobre el particular no parece justificado inferir del fragmento una alternativa entre 'contrarius consensus' y pactum, pues ambos son tratados en las fuentes con los mismos efectos procesales debido al substrato consensual que los caracteriza. Sobre la misma idea argumentativa se afirma en varias fuentes (D. 2.14.27\$2 Paulus Libro III ad Edictum y D. 2.14.7\$6 Ulpianus libro IV. Ad Edictum) que el contrarius consensus es un acuerdo resolutivo de las recíprocas obligaciones de las partes el cual constituye un pactum, por lo que aislar un concepto diferente en D. I $8 \cdot 5 \cdot 3$ Paulus Libro XXXIII ad Edictum con el fin de encontrar una contraposición de modos generales de concebir la figura no es claro. Ver A. Burdese, Recensioni a Rolf Knütel, Contrarius consensus, cit., 344; G. Gandolfi, Recensioni critiche a Knütel R. Contrarius consensus, cit., 6o2. La diferencia en el fragmento respecto a 'contrarius consensus', tal como lo demuestra la lectura del fragmento, recae en los efectos del pacto sobre las garantías que refuerzan las obligaciones de la compraventa, mas no en una diferencia de construcción dogmática de la figura.

Se duda aún más que bajo esta construcción teórica se suponga que los juristas clásicos hayan concebido el acuerdo resolutorio de un contrato consensual como un contrato civil autónomo. Bajo los cánones de la tipicidad que caracterizaba al sistema contractual romano, y en el entendido de que el contractus es solo fuente de obligaciones, tal argumentación queda sin fundamento alguno. Ver G. Gandolfi, Recensioni critiche a Knütel R. Contrarius consensus, cit., 602; A. Burdese, Recensioni a Rolf Knütel, Contrarius consensus, cit., 344. En este sentido, cualesquiera que hayan sido las divergencias entre los juristas romanos, el contractus era solamente un acto productivo de obligaciones. El sistema contractual romano clásico permaneció bajo un esquema de tipicidad y las partes no podían libremente determinar los tipos contractuales en el modo que consideraban más oportuno. Para otorgar eficacia jurídica a un simple acuerdo se debía escoger entre los tipos contractuales predispuestos por el ordenamiento. En caso contrario, el acuerdo podría tener eficacia solamente cuando dicho acuerdo pudiese ser integrado al esquema de 
lectura del fragmento al intentar comprender el caso en particular podría dar luces sobre la naturaleza jurídica del 'contrarius consensus'.

\section{I. El 'contrarius consensus' es un 'pactum' que ba de interpretarse a la luz de las exigencias de los juicios de buena fe}

El pacto, dentro del sistema contractual romano ${ }^{53}$, era entendido como un mero acuerdo de voluntad o convención entre dos o más sujetos, y carente de forma. La jurisprudencia clásica lo utilizaba para hacer referencia a un acuerdo no formal entre las partes mediante el cual determinaban los efectos jurídicos de sus relaciones negociales, siempre en el respeto de los tipos contractuales ${ }^{54}$.

El pacto se relacionaba con un principio fundamental del sistema contractual romano consistente en ex nudo pacto obligatio non oritur. El nudum pactum era entendido como aquello que no era dado en una stipulatio, que tampoco integraba dentro del plano del ius civile un supuesto de hecho típico de un contrato, ni hacía parte de aquellos casos en los que el pretor concedía una actio bonoraria55. Adicionalmente, como el pacto no se encontraba dentro de los tipos contractuales preestablecidos por el ordenamiento, no producía obligación y, por tanto, su tutela se producía mediante una excepción concedida por el pretor con el fin de paralizar la acción contractual $5^{6}$.

Dentro de esta clase de pactos se distinguían aquellos que tendían a adicionar cláusulas o que estaban orientados a modelar los efectos del contrato. Estos eran los pacta ex intervallo y los pacta in continenti: los primeros se celebraban con posterioridad o separados del contrato mismo; los otros, por el contrario, eran cláusulas convencionales anexas al contrato y que se celebraban al momento de la constitución de la relación obligatoria.

La tutela del pacto y sus efectos respecto al contrato dependían también del ámbito de actuación. Así, un pacto in continenti inherente a un contrato protegido por los iudicium bonae fidei o que fijara el contenido contractual al cual accedía sin desnaturalizar el tipo contractual, era tutelado por vía de la acción del contrato del cual hacía parte. Por el contrario, si era un pacto in continenti que se

los contratos innominados, es decir, bajo la óptica del contrato de Labeón o de Aristón. Cfr. Talamanca, Istituzioni, cit., 532 y 534; Gallo, Synallagma e conventio nel contratto, I, cit., 3 ss.

53 Sobre el particular: Talamanca, Istituzioni, cit., 607; Id., Contratto e patto nel diritto romano, cit., 32; Burdese, Manuale di Diritto Privato Romano, cit., 488; Grosso, Il sistema romano dei contratti, cit., I 7 I ss.; Id., Efficacia dei patti nei 'bonae fidei iudicia' patti e contratti en Scritti storico giuridici, III, Torino, 200 I, 84 ss.; BIondi, Iudicia bonae fidei, cit., 23 ss.; Id., Contratto e stipulatio, cit., I 3 I ss.; G. DiósDI, pacta nuda servabo?, cit., 89 ss.

54 Grosso, Il sistema romano dei contratti, cit., I72; Burdese, Manuale di Diritto Privato Romano, cit., 488 .

55 Talamanca, Istituzioni, cit., 607 .

56 Grosso, Il sistema romano dei contratti, cit., I 72. 
refería a un contrato protegido por los iudicium stricti iuris, la tutela era por vía de exceptio pacti, puesto que la acción que nacía del contrato ya estaba completamente determinada por el oportere entre las partes y no podía ser modificada por una convención posterior. Por su parte, el pacto ex intervallo solo tenía efecto sobre el contenido del contrato, y su tutela era por vía de excepción en aquellos casos en los que aliviaba la posición del obligado, es decir, aquellos pacta pro reo y no pacta pro actore.

Esta diferencia de tratamiento se debe a que cuando se hacía referencia a los pactos cuya eficacia reposaba en la inherencia de la exceptio pacti a los bonae fidei iudicium se afirmaba, por un lado, la valoración del oportere ex fide bona en el que se exigía a las partes obrar conforme a lo convenido y excluir cualquier forma de dolo; y por el otro, que los pactos contribuían a conformar el contenido de la obligación, de manera que determinaban lo que realmente querían las partes, es decir, servían para considerar la relación contractual según la voluntad efectiva de los contratantes, la cual resultaba de los pactos celebrados ${ }^{57}$, con respeto al tipo contractual $5^{8}$.

No obstante esta construcción, el 'contrarius consensus' era un caso particular, pues como era un pacto celebrado posteriormente a la celebración del contrato, no se le aplicaba la disciplina propia de los pactos ex intervallo y por consiguiente su aplicación era ipso iure 59 . Esto era debido a que, por una parte, representaba el consentimiento de las partes dirigido a la extinción del vínculo obligacional y al

57 B. Biondi, Iudicia bonae fidei, cit., 23 y 35; Id., Contratto e stipulatio, cit., I 70; M. TAlamanca, La bona fides nei giuristi romani: 'Leerformeln' e valori dell'ordinamento, en Il ruolo della buona fede oggettiva nell'esperienza giuridica storica e contemporanea, a cura di L. Garofalo, Iv, Turín, 2003, 66 ss.

58 Se sostiene que los valores que muestra la tradición civil fundada en el derecho romano encuentran en los tipos contractuales una esfera de contenido inderogable en el cual la autonomía pacticia de los privados no puede interferir. R. CARDILLI, Il problema della resistenza del tipo contrattuale nel diritto romano tra natura contractus e forma iuris, en Modelli teorici e metodologici nella storia del diritto privato 3, Nápoles, 2008, 26 ss. Por su parte, Fioni afirma que la perspectiva romana es diferente respecto a la moderna, pues la voluntad tiene actualmente una centralidad en la reglamentación de las relaciones entre privados. No obstante, la buena fe contribuye a individuar una estructura contractual típica inderogable por las partes, en el sentido de que no es posible superar los límites del tipo contractual y por conducto de la buena fe se reconduce el negocio dentro de los límites naturales del tipo, corrigiendo el contenido del contrato. Cfr. FIORI, Bona fides, cit., 22 I.

59 Tal como lo explica Biondi, el principio de la inherencia del exceptio pacti y la extinción ipso iure referida en los fragmentos D. 2.I4.58, D. 18.5.3, D. 2.14.7-6, son limitados al campo de los iudicia bonae fidei. Fuera de estos casos, el derecho clásico no admite extinción ipso iure por efecto del pacto. Cfr. BIondi, Iudicia bonae fidei, cit., 25. La tesis contraria, sostenida por Marini, considera que la eficacia de la convención resolutiva no tiene por qué ser condicionada a la inherencia del pacto a los juicios de buena fe, no se puede reducir a un plano netamente procesal. El principio de la inherencia de la exceptio pacti, invocado en sede procesal para justificar la relevancia del 'contrarius consensus', no revela el carácter civil de la figura, pues se afirma que quien le da fuerza y eficacia liberatoria ipso iure al 'contrarius consensus' es el principio de simetría que la fundamenta. Ver MarinI, Actus contrarius e pacisci nel contrarius consensus, cit., 67 . 
cual el pacto hacía referencia; y por la otra, a que ese pacto, al tener su eficacia en los bonae fidei iudicium, configuraba el contenido del contrato con los elementos que las partes le insertaban y por ello determinaba su verdadero alcance, el cual, en este caso, era la terminación del contrato ${ }^{60}$.

\subsection{Que el 'contrarius consensus' sea un 'actus contrarius' de resolución de contratos consensuales no excluye que tenga la naturaleza de 'pactum'}

Tal como se planteó, se puede afirmar que el 'contrarius consensus' estaba determinado en virtud de la emblemática regla de la simetría o correspondencia, la cual se desarrollaba bajo la idea de que existía un elemento o aspecto formal común en dos operaciones dentro del sistema contractual romano: la celebración del contrato y la extinción del mismo; por ello, se consideraba un actus contrarius. No obstante, sobresalía su carácter de convención, caracterizada por tener la fuerza necesaria para extinguir otra convención previamente celebrada y por la eficacia ipso iure sobre la parte interna del negocio al eliminar su fundamento, es decir, el consentimiento. Bajo esta óptica, se afirma que el 'contrarius consensus' era una figura que tomaba la forma de pactum en respeto de la regla clásica de simetría del actus contrarius.

Entonces, el 'contrarius consensus' nació en virtud del cumplimiento de la clásica regla de simetría, como una convención de efectos resolutivos que se aplicaba a los contratos consensuales válidamente celebrados, se configuraba como un pactum debido a la consideración de ser un acuerdo y al que no se requería forma alguna, y se basaba en el principio general de la buena fe. De esta forma, cuando se hablaba de pacto extintivo y de un acto consensual resolutivo, se estaba hablando de lo mismo: de un pactum ${ }^{6}$.

6o Sobre la tesis contraria ver Grosso, quien afirma que por la individualidad del pacto $e x$ intervallo, que solo puede producir exceptio y cuya operatividad es ope exeptionis, se explica la naturaleza autónoma del 'contrarius consensus' como acto. Si se da valor ipso iure a esta clase de pactos, también habría que reconocer la eficacia de los pactos dirigidos a alterar los elementos esenciales de un contrato: Grosso, Il sistema romano dei contratti, cit., I8 I.

6I G. DiósDI, pacta nuda servabo? Nuovi dubbi intorno ad un veccbio problema, en Bulletino dell'Istituto di Diritto romano 'Vitorio Scialoja', 74, Milán, I97 I, 89 ss., 90 ss.; B. Biondi, Contratto e stipulatio, Milán, I953, I 42 ss. A este punto conviene preguntarse cuál sería la diferencia entre el 'contrarius consensus' y el pactum de non pentendo. El pacto de non petendo es un acuerdo sin forma en el que el acreedor conviene con el deudor que no exigirá el cumplimiento de una determinada obligación; también puede consistir en el compromiso de no ejercitar una acción; paralizar una actio in rem; dilatar el pago de una deuda; o, en el caso de obligaciones subjetivamente complejas, donde existen pluralidad de sujetos, eliminar una de las obligaciones de solo uno de los sujetos. Por su parte, el 'contrarius consensus' remueve tanto la obligatio como su causa, es decir, el consentimiento. Es un pacto que priva de eficacia al contrato por virtud del querer de las partes, al eliminar recíprocamente las obligaciones emanadas del contrato bajo los límites y los parámetros que la buena fe impone. En ese sentido, aunque el 'contrarius consensus' se encuadra dentro de los modos de extinción de las obligaciones, no conserva la misma función de los otros modos pues la resolución del contrato por mutuo consentimiento, se repite, se concreta 
Así pues, del análisis de D. I 8.5.3 Paulus Libro XXXIII ad Edictum se infiere un concepto unitario del 'contrarius consensus' como un pactum conventum con su respectiva función resolutiva del acto constitutivo del contrato consensual y una específica tutela procesal negativa característica de los pactos. La diferencia en la estructuración de la figura en dicho fragmento radica en el otorgamiento de sus efectos, ope exceptionis o ipso iure, respecto al contrato. En efecto, se deduce que Juliano entiende el 'contrarius consensus' como un pacto al sostener que la tutela judicial que le corresponde a la resolución consensual del contrato es una exceptio pacti con el fin de repeler la acción de compra interpuesta por el comprador contra el vendedor; por su parte, PAulo no refuta el carácter de pacto del 'contrarius consensus' sino que simplemente se concentra en el tema de los efectos, y por ello afirma que eliminar el vínculo obligatorio principal extingue todo aquello que sea propio de la relación contractual, como son las garantías; esto es, entiende los efectos del pacto sobre el oportere ex fide bonae.

En cuanto a este análisis, falta determinar en D. 18.5.3 Paulus Libro XXXIII ad Edictum la razón por la cual PAulo reconocía efectos extendidos al 'contrarius consensus' en el entendido de que no solo se limitaba a resolver el contrato consensual emptio venditio, y por consiguiente a liberar al deudor, sino que comportaba la liberación también del fiador, liberato reo et fideiussorem liberari. De esta forma, Paulo se alejaba de la estructura propuesta por Juliano, quien consideraba que los efectos del 'contrarius consensus' eran solo sobre el contrato consensual que estaba llamado a resolver, y no sobre las garantías. Esta cuestión permite, por medio del fragmento objeto de análisis, determinar cuáles eran los efectos del 'contrarius consensus' frente al contrato, especialmente, en lo que respecta a sus garantías.

\subsection{Los efectos del 'contrarius consensus' frente al contrato se debaten entre la extinción 'ope exceptionis' e 'ipso iure'. El caso de las obligaciones que garantizan la compraventa}

$\mathrm{Al}$ ser la compraventa un contrato consensual que puede disolverse por 'contrarius consensus', siempre y cuando no se hayan ejecutado las prestaciones, se pregunta, en el caso de que existan garantías o reforzamiento de las prestaciones de la compraventa, por ejemplo mediante un fiador o una estipulación novatoria, como se presenta en D. I 8.5.3 Paulus Libro XXXIII ad Edictum, ¿qué efectos tiene el 'contrarius consensus' sobre las obligaciones que refuerzan la compraventa? 
En efecto, el fragmento toca las siguientes problemáticas: la primera, referida a la disolución o no por el efecto del 'contrarius consensus' de las obligaciones del garante del adquirente; la segunda, concerniente a la admisibilidad de la resolución consensual de la obligatio ex stipulatio que formaliza la obligación del pago del precio del comprador a favor del vendedor ${ }^{62}$.

Se reporta en el fragmento la opinión de Juliano sobre los efectos de la nuda voluntad en las obligaciones del fiador y en la estipulación del comprador, cuando indica que "ciertamente no puede ejercitarse la acción de compra, porque las excepciones del pacto se hallan comprendidas en el juicio de buena fe; pero se ha de ver, si tendrá el fiador la excepción útil"63. El jurista está considerando, por una parte, la naturaleza jurídica del pactum que tiene el 'contrarius consensus', al expresar que no procedería la acción ex empto pues el contrato de compraventa fue resuelto por el consentimiento mediante un pacto cuya eficacia se encuentra dentro del ámbito relativo a los iudicium bonae fidei, trayendo como consecuencia que el juez deba tener en cuenta el pacto contrario, esto es, el 'contrarius consensus', y por ello la paralización de dicha acción; por otra, que los efectos del 'contrarius consensus' recaen inicialmente solo sobre el negocio que las partes celebraron, es decir, el contrato de compraventa, puesto que existe duda para Juliano sobre la aplicabilidad del 'contrarius consensus' en la relación obligacional del fiador aceptado por el vendedor y en la estipulación asumida por el comprador, al expresar que "se ha de ver si el fiador tendrá la excepción útil"64 - an autem fideiussori utilitis sit exceptio, videndum-65.

62 R. Cardilli, Iulianus XV Digestorum (D. I 8,5,5,I-2) e limiti al contrarius consensus, cit., I49 n. 9. Comparte la idea de que en el fragmento en cuestión no existe una incoherencia sobre el reclamo al vendedor, pues en la primera parte del texto se habla de una novación estipulatoria solo por parte del vendedor, mientras en las conclusiones se hace referencia al caso en el cual sea el vendedor quien obre ex stipulatu frente al comprador, tal como se afirma en V. ManNino, L'estensione al garante delle eccezioni del debitore principale nel diritto romano classico, Turín, I992, 59, n. 52 .

63 D. 18.5.3 Paulus Libro XXXIII ad Edictum: “(...) Iuliano scripsit ex empto quidem agi non posse, quia bonae fidei iudicio exceptiones pacti insunt: an autem fideiussori utilitis sit exceptio, videndum (...)".

64 El carácter de utilidad de la excepción es en este caso en sentido genérico y no técnico. R. CardiLli, Iulianus XV Digestorum (D. I 8,5,5,I-2) e limiti al contrarius consensus, cit., I49, n. I I. En el mismo sentido, la referencia a la utilidad de la excepción debe ser entendida en términos de las ventajas que trae el ejercicio de la excepción por su justo titular, mas no como la extensión del ejercicio de una exceptio pacti; es decir, el fiador que no participó en la celebración del 'contrarius consensus' no puede alegar la excepción. De esta manera, se sostiene que los clásicos consideraban por regla la negación de la extensión de la exceptio pacti a los garantes. Ver F. De Martino, Le garanzie personali dell'obbligazione, I, Treccani, Roma, i940, 2 I i. Por ello, se rechazan las interpretaciones que realizan sobre el particular: (i) GuARINo, quien, basado en su interpretación del fragmento Paul. 33 ad Edictum D. I8.5.3, sostiene la idea de que Paulo declara previamente en términos generales el carácter consensual de la compraventa y su posibilidad de disolución consensual siempre y cuando no se hayan ejecutado las prestaciones del contrato; para luego referirse a si por el efecto mediato del 'contrarius consensus' vienen a ser disueltas la obligatio asumida por el fiador a favor del vendedor y la obligatio ex stipulatu que el comprador asumió, en novación de la obligatio ex voluntate, al vendedor. El precedente al cual Paulo se refiere es una opinión de Juliano sobre un caso concreto: una venta disuelta 
Juliano recurre al principio de la inherencia de la exceptio pacti a los bonae fidei iudicium para justificar en sede procesal la relevancia del 'contrarius consensus', pero no traslada al plano del derecho sustancial el reconocimiento de la relevancia civilista del mismo en el sentido de disolver las particulares obligaciones que refuerzan la compraventa. Entonces, el jurista no afirma los efectos de liberación ipso iure del 'contrarius consensus' sobre las obligaciones del fiador y de la estipulación asumida por el comprador, en el entendido de que estas son obligaciones formales en las que se conserva, para él, el principio de simetría entre el acto de constitución y el acto de disolución. En ese orden de ideas, la liberación de las garantías se puede alegar ope exceptionis en el entendido de que, al ser una obligación nacida verbis, no puede resolverse por un nudo pacto, pero sí por los efectos de la extensión del pacto al garante. De ahí viene el sentido de utilis referido en el fragmento: si al fiador le puede traer ventaja la excepción.

Paulo, por su parte, luego de citar a Juliano, se limita a determinar que la obligación del fiador corre la misma suerte que la del deudor, et puto liberato reo et fideiussorem liberari, es decir, sostiene que si es liberado el deudor, debe entenderse liberado el fiador. Con esta afirmación el jurista se aleja de la posición de Juliano al extender los efectos ipso iure del 'contrarius consensus' a las garantías del contrato de compraventa.

La razón que justifica tal extensión de los efectos del 'contrarius consensus' en D. I 8.5.3 Paulus Libro XXXIII ad Edictum por parte de Paulo, puede radicar en la manera de entender por parte del jurista severiano la función de la stipulatio dentro de su momento histórico. Así, desde los inicios del siglo in a.C. se muestra, por ejemplo, cómo en los formularios negociales contenidos en De agricultura de Catón se garantizan las obligaciones de una conventio a través de una stipulatio mediante la siguiente interrogatio: haec quae supra scripta sunt, ea ita dari fieri neque adversus ea fieri spondes? -lo que fue anteriormente escrito, ¿tú me prometes que sea dado y hecho en el modo antes dicho y que no se haga nada en contra-

mediante un pactum ex intervalo luego de lo cual el vendedor quiera igualmente accionar para obtener la prestación a cargo del comprador. Juliano escribe que no es posible, ya que al estar las excepciones del pacto dentro del juicio de buena fe, serán alegadas por la parte demandada contra el demandante. Con posterioridad al comentario del jurista clásico, PAulo, al aplicar el argumento general de Juliano al caso específico de una venta disuelta mediante pactum, responde que la exceptio pacti, así como le es útil al vendedor convenido, también lo es para los garantes, y del mismo modo lo es para el comprador en el juicio que sea promovido en contra de él. Ver A. Guarino, Per la storia del 'contrarius consensus', cit., 280; en el mismo sentido P. Frezza, Le garanzie delle obbligazioni, Corso di Diritto Romano, I, Padova, I962, I Io; (ii) Mannino afirma que tal utilidad se traduce en extender la exceptio pacti al fiador, con base en que el normal interés del deudor principal es evitar el retroceso del garante al juicio y que recaigan los riesgos del contrato sobre él. Cfr. Mannino, L'estensione al garante delle eccezioni del debitore principale, cit., 6I ss.

65 Schipani sugiere que la traducción del latín al italiano que se debe realizar sobre la expresión en particular es "ma si deve vedere se l'eccezione possa tornare di vantaggio al fideiussore": Schipani, Iustiniani Augusti Digesta seu Pandectae, testo e traduzione, Milán, 2005, 380. 
rio?-. Esto trae como consecuencia que la conventio influya posteriormente en la eficacia de la stipulatio, tanto así que, para la época de PAulo, la jurisprudencia severiana acentuó el carácter instrumental de la stipulatio como medio para dar eficacia formal a un conjunto de disposiciones sobre el cual estaba conformado el acuerdo entre las partes, lo que trajo que tal acuerdo sea la causa de la stipulatio ${ }^{66}$.

Bajo esta óptica, cabe inferir que Paulo respeta la regla de simetría entre el acto de celebración y el de extinción para la terminación de los contratos, pero es claro que la causa de la obligación del fiador es el reforzamiento de las obligaciones surgidas del contrato de compraventa; al no existir estas, no tiene razón alguna aquella. A partir de esta idea se concluye que los efectos liberatorios que le surgen al fiador por conducto del 'contrarius consensus' se deben a la eliminación de la causa de la obligatio ex stipulatio ${ }^{67}$.

Esta argumentación aparece perfectamente en sintonía, dentro del ámbito de la jurisprudencia severiana, con aquello que PAPINIAno sostiene en D. $46 \cdot 3 \cdot 95^{[68]}$, en donde se hace referencia al 'contrarius consensus'. El jurista, contemporáneo de Paulo, sostiene que en los casos en los que las partes de una compraventa la hayan resuelto por mutuo consentimiento, el fiador queda libre por no existir el contrato principal. En efecto, se comprueba que la orientación del pensamiento de Paulo se dirigía a considerar el carácter instrumental de la stipulatio, en el sentido de garantía respecto a la convención principal; todo esto trae como consecuencia la posibilidad de extender los efectos del 'contrarius consensus' a las obligaciones que garantizan el contrato que se quiere resolver.

Por último, Paulo expresa que los garantes tienen una exceptio en aquellos casos en los cuales el acreedor desconoce los efectos del 'contrarius consensus' y

66 Talamanca, Istituzioni, cit., 565 ss.

67 No obstante esta interpretación, BuRdese afirma que la disparidad de soluciones sostenidas por Juliano y Paulo sobre la aplicabilidad del 'contrarius consensus' en el caso de las obligaciones que acompañan el contrato de compraventa de que trata D. I $8.5 \cdot 3$ se debe a la falta de conocimiento por parte de Juliano del carácter general de accesoriedad de la fianza, reconocido en cambio por Paulo: ver Burdese, Recensioni a Rolf Knütel, Contrarius consensus, cit., 347. En el mismo sentido Mannino, L'estensione al garante delle eccezioni del debitore principale, cit., 63. Otra interpretación posible es la que afirma que el 'contrarius consensus' no hace referencia a una renuncia al derecho que nace del crédito, sino que, tratándose de un pacto que se refiere a un contrato sinalagmático cuyas obligaciones recíprocas se resuelven por la fuerza de la voluntad, explicaría por qué el acuerdo podría ser suficiente para extinguir también la relación con el fiador, pero jamás para extenderle la legitimidad sobre las excepciones, pues el problema del otorgamiento de las excepciones no se soluciona con el dogma del carácter accesorio de las garantías de la obligación principal sino con la naturaleza de cada particular exceptio. Ver DE Martino, Le garanzie personali dell'obbligazione, cit., 2 I 3 ss.

68 D. 46.3 .95 \$1 2. Papinianus libro XXVIII. Quaestionum: "Si inter emtorem et venditiorem convenerit, priusquam aliquid ex alterutra parte solveretur, ut ab emtione discedatur, fideiussor eo nomine acceptus soluto contractu liberabitur" ("Si entre el comprador y el vendedor se hubiere convenido separarse de la compra, antes que por una u otra se entregase cosa, el fiador admitido en tal negocio quedará libre por haberse disuelto el contrato": trad. de García del Corral, Cuerpo del Derecho Civil Romano, Digesto, III, cit., 6I 6). 
acciona contra ellos una actio ex stipulatu. Aunque no se determina el tipo de excepción, y teniendo en cuenta que no puede ser una exceptio pacti, pues esta no es extensible a los garantes ${ }^{69}$, el tipo de excepción llamada a prosperar contra la actio ex stipulatu es la exceptio doli $7^{\circ}$, puesto que el hecho de accionar contra los garantes, con conocimiento de los efectos extintivos sobre el contrato de compraventa y la consecuente extinción de las garantías por inexistencia de la causa, se convierte en un comportamiento doloso, contrario a la bona fides, esto es, al genérico deber de comportarse según los cánones de la corrección ${ }^{7 \mathrm{I}}$.

En conclusión, el fragmento D. I 8.5.3 Paulus Libro XXXIII ad Edictum enseña el carácter de pactum y los efectos ipso iure que tiene el 'contrarius consensus' respecto del contrato, y específicamente sobre las obligaciones que se hayan adicionado con el fin de garantizar el cumplimiento del contrato principal. Estos efectos están advertidos en dos posturas de juristas romanos, el primero y más antiguo, Juliano, que solo reconoce efectos sobre la convención principal, y el otro, Paulo, que admite efectos más amplios, incluyendo las garantías.

\section{Los límites al 'contrarius consensus'}

Por la importancia del 'contrarius consensus' en la experiencia jurídica romana, resulta de sumo interés evidenciar los límites que se imponen a la figura para que su aplicación sea razonable y justa, en el sentido de garantizar a las partes el cumplimiento del fin por el cual celebraron el acuerdo resolutorio y evitar situaciones desventajosas para alguna de ellas. Así las cosas, la aplicación del 'contrarius consensus' no puede ser tan amplia puesto que se podrían desfigurar sus contornos y por ende se la convertiría en imprecisa, al punto que todo contrato consensual podría resolverse sin parámetro alguno, en contra de los dictados de la buena fe.

Por consiguiente, la resolución del contrato consensual por mutuo acuerdo de las partes, a partir del análisis casuístico propio del derecho romano, está demarcada por la exigencia de que no hayan sido ejecutadas las prestaciones que emanan del contrato, el equilibrio del vínculo contractual y la pérdida de la cosa.

\section{I. La 'res integra'}

El 'contrarius consensus' tiene una limitación en su ámbito de aplicabilidad, consistente en la exigencia de la res integra, esto es, la falta de cumplimiento de las

69 Ver supra, n. 69.

70 E. Costa, L'exceptio doli, Roma, I970, 76.

7 I F. Milone, La exceptio doli (generalis), Studio di diritto romano, Roma, I970, 59 ss.; Costa, L'exceptio doli, cit., 76; Neme Villarreal, La buena fe en el derecho romano, Extensión del deber de actuar conforme a la buena fe en materia contractual, cit., I80, n. 6 Iо. 
obligaciones que derivan del contrato. Así, la admisibilidad de la figura está determinada por la no ejecución de las prestaciones del contrato bajo los criterios generales de la bona fides.

Son varias las fuentes ${ }^{72}$ que hacen referencia a tal exigencia, lo que parece indicar que el requisito es de origen clásico. Además, este requisito tiene tres razones de ser: garantizar la coherencia dentro del sistema contractual romano; el hecho de que el carácter extintivo de la ejecución de las prestaciones nacidas del contrato haga inoperante el 'contrarius consensus'; y el que resolver un contrato por mutuo acuerdo cuando una de las prestaciones ha sido ejecutada generaría una situación de desequilibrio en la relación contractual.

En efecto, la exigibilidad de la res integra hace que exista una coherencia del 'contrarius consensus' respecto al sistema contractual romano pues, al ser considerada la resolución consensual del contrato como un pactum, solo puede tutelarse judicialmente mediante una exceptio, y no por medio de una actio, que solo se concede a los contratos. Entonces, permitir que las prestaciones se ejecuten y luego celebrar un acuerdo resolutorio sobre el contrato ejecutado, por ejemplo mediante una datio a una de las partes, podría generar alguna situación obligacional posterior ${ }^{73}$, y por lo tanto la posibilidad de que del pacto resolutorio nazcan acciones dirigidas a la restitución de aquello que fue dado por una de las partes, lo cual va en contra, se repite, de la regla consistente en que de un pacto no se produce acción sino excepción ${ }^{74}$. Así, la razón de la res integra como presupuesto del 'contrarius consensus' no es de carácter teórico sino más bien práctico, consistente en la preocupación de garantizar la coherencia dentro del sistema.

Al lado de esta fundamentación, se sostiene que la inadmisibilidad de un acuerdo entre las partes dirigido a la extinción del vínculo después de ejecutadas las prestaciones, tiene como sustento la convicción de las partes de que de la ejecución de las prestaciones del contrato deriva un estado de cosas definitivo en el mundo externo: la extinción de las obligaciones que surgen del contrato debido al pago y el cumplimiento de lo acordado en el contrato. Por lo anterior, el 'contrarius consensus' no podría oponerse contra un crédito ya extinguido ${ }^{75}$; o en su defecto, en caso de existir un pacto dirigido a la extinción de un vínculo obligatorio, faltaría la existencia de tal vínculo por haberse suprimido debido al cumplimiento. Son por lo tanto irreconciliables los conceptos de extinción por ejecución de la prestación y de resolución del contrato, pues la eventual

72 D. г 8.5.5 \$ I Iulianus Libro XV. Digestorum; D. г 8.5.3 Paulus Libro XXXIII ad Edictu; D. г 8. г.72 pr. Papinianus Libro X. Quaestionum; D. 18.5.2 Pomponius libro XXIV ad Sabinum; D. I8.1.6 2 Pomponius Libro IX ad Sabinum.

73 Cfr. Cerami, Risoluzione del contratto, Diritto romano, cit., I 282.

74 G. Grosso, L'efficacia dei patti nei 'bonae fidei iudicia', cit., 7 y I 3.

75 G. Gandolfi, Recensioni critiche a Knütel R. Contrarius consensus, cit., 599; A. Burdese, Recensioni a Rolf Knütel, Contrarius consensus, cit., 344. 
ejecución de las obligaciones del contrato, en principio, significa una implícita confirmación de las disposiciones establecidas en el reglamento contractual por las partes ${ }^{7}$.

\section{I.I. La 'res restituta' como equiparación de la 'res integra': regreso al equilibrio inicial de la relación negocial que se quiere resolver}

En una sententia de ARISTón -referida por Neracio en D. 2.I $4 \cdot 5^{877]}$ - puede advertirse que se redimensiona la res integra, sobre unas bases que conviene examinar para entender cómo se determina la res integra en el caso concreto, teniendo en cuenta el rol de la buena $\mathrm{fe}^{78}$.

76 Existe una rica casuística sobre el requisito de la absoluta inejecución de las obligaciones del contrato: rebus adhuc integris. Específicamente en aquellos casos en los que se discute la subsistencia o no de la res integra. El primero de ellos es la intervención de un fiador en la compraventa (D. 18.5.3 Paulus Libro XXXIII ad Edictum); el segundo, la situación en la cual se hace la deducción de una obligatio consensu contracta por una stipulatio (D. I8.5.3 Paulus Libro XXXII ad Edictum); y por último, el caso en el que se realiza la entrega de las arras confirmatorias (D. I9. I.I I.6 Ulpianus XXXII ad Edictum). En todos estos casos se admite la subsistencia de la res integra y por consiguiente la posibilidad de resolver el contrato convencionalmente. Cerami, Risoluzione del contratto, Diritto romano, cit., I 282.

77 D. 2.14.58 Neratius libro III. Membranarum: "Ab emptione, venditione, locatione, conductione, cesterisque similibus obligationibus, quin integris ómnibus consensu eorum, qui inter se obligati sint, recedi possit, dubium non est. Aristoni hoc amplius videbatur, si ea, quae me ex empto praestare tibi oporteret, praestitissem, et cum tu mibi pretium deberes, convenisset mibi tecum, ut rursus praestitis mibi a te in re vendita ómnibus, quae ego tibi praestitissem, pretium mibi non dares tuque mibi ea praestitisses: pretium te debere desinere; quia bonae fidei, ad quam omnia baec rediguntur, interpretatio hanc quoque conventionem admittit. Nec quidquam interest, utrum integris ómnibus, in quac obligati essemus, conveniret, ut ab eo negotio discenderetur, an in integrum restitutis his, quae ego tibi praestitissem, consentiremus, ne quid tu mibi eo nomine praestares. Illud plane conventione, quae pertinet ad resolvendum id quod actum est, prefici non potest, ut tu quod iam ego tibi praestiti, contra praestare mohi congaris; quia eo modo non tam hoc agitur, ut a pristino negotio discedamus, quam ut novae quaedam obligationes inter nos constituantur" ("No se duda que por el consentimiento de todos los que entre sí se hubieren obligado sea posible separarse de una compra, venta, locación, conducción, y de las demás obligaciones semejantes, con tal que todas estén íntegras. A Aristón aún parecía bien esto, que si yo te hubiese entregado lo que convenía que yo te entregara por razón de una compra, y debiéndome tú el precio, me hubiese convenido contigo, para que, habiéndoseme reintegrado por ti respecto a la cosa vendida todo lo que yo te hubiese entregado, no me dieses el precio, y tú me hubieses reintegrado aquello, dejabas de deber el precio; porque la interpretación de la buena fe, a que todas estas cosas se refieren, admite también esta convención. Y nada importa, o que, hallándose íntegras todas las cosas sobre que nos hubiésemos obligado, se conviniera el apartarse de tal negocio, o que, restituidas por entero las que yo te hubiere entregado, consintiéramos que tú no me dieras nada por semejante motivo. Verdaderamente, por la convención que se dirige a revocar lo que se efectuó, no puede hacerse que lo que yo ya te entregué, seas tú por el contrario obligado a entregármelo; porque de este modo, no se trata tanto de que nos apartemos del primitivo negocio, como de que entre nosotros se constituyan obligaciones nuevas": trad. de García del Corral, Cuerpo del Derecho Civil Romano, Digesto, I, cit., 290).

78 Fiori, Bona fides, cit., 235 ss.; Talamanca, La bona fides nei giuristi romani, cit., ioo ss.; E. STolfi, Bonae fidei interpretatio. Ricerche sull'interpretazione di buona fede fra esperienza romana e tradizione romanistica, Nápoles, 2004, 3 I ss. 
La primera parte del texto indica que no existe duda sobre la regla que establece la resolución de contratos consensuales mediante el consentimiento siempre que se mantengan las prestaciones incólumes. Luego, bajo un ejemplo, se plantea el caso de una compraventa en la que el vendedor había entregado la mercancía y el comprador no había pagado el precio. Aristón sostenía que las partes podían resolver igualmente el negocio de compraventa siempre y cuando el comprador hubiera restituido espontáneamente la mercancía recibida, pues según el jurista, la interpretación de la buena fe, a que todas estas cosas se refieren, admite también esta clase de acuerdos -quia bonae fidei79, ad quam omnia haec rediguntur, interpretatio banc quoque conventionem adminittit-.

La parte siguiente del fragmento -referida por Neracio, quien a su vez se fundamenta en Aristós ${ }^{80}$ - describe dos supuestos de hecho: el primero, si las prestaciones están sin ejecutar, es posible apartarse del negocio por mutuo acuerdo; el segundo, que previa restitución espontánea de las cosas entregadas en cumplimiento de las obligaciones del contrato, y con el acuerdo de no derivarse nuevas obligaciones de tal restitución, también es posible apartarse del negocio. En ambos casos lo verdaderamente importante es que la convención, por la cual las partes desean terminar el vínculo contractual, no les genere obligaciones nuevas sino que resuelva el negocio originario.

En este orden de ideas, se afirma que esta fuente evidencia que los romanos sostenían la imposibilidad de proceder a la disolución de un contrato cuyas prestaciones se hubieran ejecutado, salvo que los contratantes hubieran restituido lo recibido en aras de volver el contrato al status quo ante. De esta manera, el acto de restitución no puede ser visto como una obligación posterior a la resolución del contrato, sino como la manera de conformar la res integra para luego dar lugar a la admisibilidad del 'contrarius consensus'.

Entonces, si se acepta que la tradición de la cosa vendida adiciona elementos al contrato puramente consensual de la compraventa -como la obligación de garantizar la inexistencia sobre los vicios de la cosa-, de manera que hace imposible la resolución por 'contrarius consensus', también se puede admitir que la restitución de la cosa recibida adiciona a la convención que se quiere resolver la posibilidad de ser eliminada, pues se regresa al estado anterior a la ejecución de la prestación del contrato en cuestión ${ }^{8 \mathrm{r}}$.

79 Se considera que la expresión interpretatio bonae fidei fue insertada por los justinianeos con fundamento en el deseo de apelar al principio de la buena fe para así derivar la eficacia del 'contrarius consensus' respecto de los iudicia bonae fidei. Cfr. Grosso, Efficacia dei patti nei 'bonae fidei iudicia', cit., I8; Además se afirma que la expresión de interpretatio no está conectada con el sintagma bona fides. Talamanca, La bona fides nei giuristi romani, cit., I03, n. 289. Se abandonan tales consideraciones pues el fundamento del parecer de ARIstón es exactamente la bona fides: ver FIORI, Bona fides, cit., 235.

8 o Ibíd., 236.

8 I Grosso, Efficacia dei patti nei 'bonae fidei iudicia', cit., I9. 
Ahora, en cuanto al rol de la buena fe respecto del 'contrarius consensus', es de precisar que dicho rol se enmarca en la función normativa característica de la bona fides ${ }^{82}$, pues reglamenta un caso de res integra que permite la operatividad del 'contrarius consensus' aun cuando se hayan ejecutado las prestaciones. Por ello, la interpretatio realizada por los prudentes sobre la noción de la bona fides en el caso concreto va dirigida a darle validez al 'contrarius consensus' en tanto se respete el equilibrio de la relación contractual ${ }^{83}$, lo cual se realiza con la res restituta. Se evidencia entonces una equiparación de la res restituta a la res integra ${ }^{84}$.

\section{2. 'Periculum rei venditae'}

Dentro de las fuentes en las que se pone de relieve a la res integra como elemento determinante para la aplicación del 'contrarius consensus', se encuentra un testimonio de Juliano en el que se expresa un límite adicional a la operatividad de la figura, consistente en la imposibilidad de su aplicación en aquellos casos en los que la cosa objeto del contrato ha perecido. Tal testimonio es D. I 8.5.5 $\$$ I y $\$ 2$ Iulianus Libro XV. Digestorum ${ }^{85}$, en el que Juliano sostiene la posibilidad de extinguir una compraventa con el simple consenso siempre y cuando no se haya dado inicio a la ejecución de las prestaciones, es decir, no sea exigible la res integra. Luego expone el caso en el cual el objeto del contrato de compraventa es un esclavo y este muere. El jurista considera que la venta debe ser tratada del mismo modo que si hubiese sido entregado el esclavo, y por lo tanto se genera la respec-

82 Fioni, Bona fides, cit., 238 , n. $43^{8}$.

83 Fiori, Bona fides, cit., 238. En el mismo sentido SToll explica que la interpretatio era una operación compleja pues no era suficiente el reenvío a la buena fe para dar solución al caso concreto. Si fuese una situación en la que el acuerdo que resuelve la relación negocial se hiciera antes del cumplimiento de alguna de las prestaciones nacidas del contrato, la solución estaría dirigida, a la luz del criterio de la inherencia de la exceptio pacti, a los bonae fidei iudicium; pero, en la sentencia de Neracio, la bona fides orientaba la reflexión jurisprudencial para admitir una conventio resolutiva en donde ya fueron ejecutadas las prestaciones. Stoll, Bonae fidei interpretatio, cit., 43 .

84 Fioni, Bona fides, cit., 238. La tesis contraria es sostenida por Talamanca, quien considera que Aristón conecta la decisión a la bona fides, y más explícitamente funda la solución puntual pretium te debere desinere sobre el hecho de que también la conventio en cuestión pertenece a lo que la bona fides impone proteger: la conexión de la buena fe con la protección de la palabra dada en un contexto en el que el jurista afronta los límites del ordenamiento. Cfr. Talamanca, La 'bona fides' nei giuristi romani, cit., I04.

85 D. I 8.5.5 Iulianus Libro XV. Digestorum: "S I.- Emtio nuda conventione dissolvitur, si res secuta non fuerit. $\int$ 2.- Mortuo autem homine perinde babenda est venditio, ae si traditus fuisset, utpote quum venditor liberetur, et emtiori homo pereat; quare, nisi iusta conventio interervenerit, actiones ex emto et vendito manebunt" ("\$ I.- La compra se disuelve por la nuda convención, si el negocio no se hubiera realizado. $\$ 2$.- Pero muerto el esclavo, se ha de considerar la venta lo mismo que si hubiese sido entregado, como quiera que el vendedor quedaría libre, y el esclavo perecería para el comprador; por lo cual, si no hubiere mediado justa convención, subsistirán las acciones de compra y venta": trad. de García del Corral, Cuerpo del Derecho Civil Romano, Digesto, I, cit., 920). 
tiva liberación del vendedor y la obligación del comprador de soportar la pérdida del esclavo. Con base en esto se podrían aún ejercitar las acciones de compra y venta, a menos que no haya intervenido un justo acuerdo entre las partes ${ }^{86}$.

El aspecto problemático en este fragmento consiste en el reconocimiento de la común voluntad de las partes de resolver el contrato una vez muerto el esclavo vendido, y por lo tanto en la imposibilidad de su entrega por el vendedor al comprador. Adicionalmente, su lectura exegética permite no encausarlo únicamente ni bajo la problemática del periculum emptoris en la compraventa ${ }^{87}$, ni

86 Se llama la atención sobre la problemática de la palingenesia del texto. Como supone LeneL, Palingenesia iuris civilis. Volumen prius, cit., I034, la conformación del fragmento D. I8.5.5 debería estar integrada en el parecer de Juliano que es invocado por Paulo en D. i 8.5.3 Paulus Libro XXXIII ad Edictum. En este sentido, entre los parágrafos I y 2 del actual orden debe entenderse insertado D. I8.5.3. Así el fragmento expresaría: en el primer parágrafo, la regla general en la que se plantea la condición de res integra para la aplicación del 'contrarius consensus'; posteriormente, los efectos del 'contrarius consensus' en los casos en que se presentan garantías en las obligaciones principales; y por último, la limitación de celebrar una conventio resolutoria de un contrato en el cual hay pérdida de la cosa objeto del contrato, lo que genera la imposibilidad de cumplimiento del contrato a resolver.

Además, se cree que la hipótesis palingenésica de Lenel no está basada en la idea de que los compiladores recortaron el fragmento para evitar repeticiones sobre la res integra (pues de la lectura de D. 18.5.3 Paulus Libro XXXIII ad Edictum, así como de la de D. 18.5.5 Iulianus Libro $x V$. Digestorum, se concluye que trata del tema de la condición res integra para la eficacia del 'contrarius consensus') sino en el planteamiento de dos hipótesis que se presentan respecto a la operatividad del 'contrarius consensus' y la integralidad de la res integra, es decir, en D.r8.5.3 se trata de los efectos sobre el fiador, y en D.18.5.5\$2, de la aplicación del 'contrarius consensus' en caso de pérdida de la cosa.

Sobre esto último y a favor de la conexión que existe en D. I8.5.5 $\$ 2$ con 'contrarius consensus' se argumenta, con una menor fuerza, el hecho de que el fragmento está ubicado dentro de la compilación justinianea en el título $\mathrm{v}$ que hace referencia a de rescindenda venditione, et quando licet ab empione discedere (de la recisión de la venta y cuándo es lícito apartarse de la compra), y no específicamente dentro del título vi que hace referencia a de periculo et commodo rei venditae (del riesgo y del beneficio de la cosa vendida). Sumado a esto, se sostiene que existe una sintonía entre la expresión de D. I8.5.5 \$ I: "Emtio nuda conventione dissolvitur, si res secuta non fuerit", y aquella del $\$ 2$ al hablar de iusta conventio, pues se trata de una terminología que se conecta y se cristaliza con el texto expresado en D. I8.5.2 Pomponius libro XXIV ad Sabinum: “(...) potest enim, dum res integra est, conventione nostra infecta fieri emtio (...)" (porque es posible mientras está integro el negocio, que por convenio nuestro se anule la compra"). Ver CARDILLI, Iulianus $\mathrm{XV}$ Digestorum (D. I 8,5,5,I-2) e limiti al contrarius consensus, cit., I 50 ss.

87 Esta aproximación es sostenida por CARDILLI, quien explica cómo existe una tendencia a separar los parágrafos dentro del fragmento, de manera que se acentúa la lectura de la opinión de Juliano sobre una interpretación de la regla del periculum rei venditae en el derecho romano clásico. En ese sentido, para los que apoyan el carácter clásico de la regla periculum est emptoris, el paso viene leído como una evidente atribución del evento "muerte a cargo del comprador", emptori homo pereat, antes de la traditio, desmintiendo el requisito de emptio perfecta como criterio de atribución del riesgo al compradorl, y al mismo tiempo recurriendo a una fictio traditionis para justificar la asignación al comprador de la muerte del esclavo antes de la traditio. Cfr. Cardilli, Iulianus XV Digestorum (D. I 8,5,5, I-2) e limiti al contrarius consensus, cit., I 5 I ss. Sobre el particular ver M. SARGENTI, Rischio contracttuale, Diritto romano, en ED, XL, Milán, I989, i 2 7; M. Talamanca, Vendita in generale, Diritto romano, en ED, Xlvi, Milán, I993, 453; Id., Considerazioni sul periculum rei venditae, en Seminarios Complutenses de Derecho Romano, 7, I995, 253; E. Betтi, Periculum, Problema del rischio contrattuale in diritto romano classico e giustinianeo, en Studi in onore di P. De Francisci, Milán, I956, I79 ss.; R. Cardilli, L'obbligazione di praestare 
tampoco bajo la hipótesis de considerar la muerte del esclavo como ejecución de la prestación por el vendedor ${ }^{88}$.

En efecto, el caso de la muerte del esclavo dentro de la perspectiva de JuLIANo es un hecho que le lleva a plantear el carácter inoperante del 'contrarius consensus' para disolver el contrato consensual, y por ende, a establecer un límite a la resolución consensual de la obligatio consensu contracta.

Bajo esta interpretación es posible entender la integralidad del fragmento en los siguientes términos: una vez negada la capacidad de disolver la compraventa por 'contrarius consensus', Juliano determina que los efectos a nivel procesal respecto de la muerte del esclavo están establecidos por la regla del contrato, y por lo tanto se entiende liberado el vendedor de entregar la cosa y obligado el comprador a pagar el precio convenido. Luego, el jurista clásico termina su razonamiento evidenciando que si la conventio resolutoria no es iusta conventio por no encontrarse res secuta, entonces es incapaz de terminar la compraventa y por lo tanto las acciones nacidas del contrato quedan a favor de las partes ${ }^{8}$.

Así pues, la ratio del texto va dirigida a equiparar la muerte del esclavo al cumplimiento de las prestaciones principales del vendedor, y así, a sostener que tal hecho impide valorar la conventio resolutoria como idónea para producir sus normales efectos extintivos sobre el contrato de compraventa. Esto es, imponer un límite a la operatividad del 'contrarius consensus'.

Entonces, el último corifeo de la escuela sabiniana entiende que la eficacia del 'contrarius consensus' posterior a la emptio depende objetivamente de dos eventos: el primero, el no inicio de ejecución de las prestaciones nacidas del contrato, si res secuta non fuerit -así por ejemplo, en el caso en que el 'contrarius consensus' sea celebrado después de la traditio, tal acuerdo no tendrá la capacidad extintiva sobre el vínculo-; el segundo, el caso res perit, como sucede cuando la conventio resolutiva interviene después de la muerte del esclavo vendido, pues dicha conventio pierde su fuerza extintiva sobre la compraventa.

Este último evento, tal como sostiene CARDILLI, demuestra una concepción rigurosa de Juliano sobre el contrato, pues extiende a un hecho independiente de la voluntad de las partes, como lo es la muerte del esclavo vendido, los efectos propios de la ejecución de una de las prestaciones principales para evitar que las partes desconozcan su acuerdo. Tanto es así que la voluntad de las partes de resolver el contrato por mutuo acuerdo significaría no asumir por el comprador el hecho de la muerte del esclavo con base en las reglas de distribución del pe-

e la responsabilità contrattuale in diritto romano, Milán, i995, 3 I I ss.; M.L. Neme Villarreal, Los principios generales del derecho y el problema de los riesgos por pérdida de la cosa debida, en Roma e America, Diritto romano comune, 2 I, Roma, 2006, 2 I 2 ss. [= Revista de Derecho Privado, Universidad Externado de Colombia, n. ${ }^{\circ}$ I 5 , Bogotá, 2008].

88 Cerami, Risoluzione del contratto, Diritto romano, cit., I 284.

89 R. Cardilli, Iulianus XV Digestorum (D. I 8,5,5,I-2) e limiti al contrarius consensus, cit., I 54. 
riculum en la compraventa, lo cual, en opinión del jurista, no sería compatible con la regla sabiniana potest, enim, dum res integra est, conventione nostra infecta fieri emptio -es posible mientras está íntegro el negocio, que por convenio nuestro se anule la compra-, de la cual habla Pomponio en D. i 8.5.2 libro XXIV. Ad Sabinum $^{9}$. Esta perspectiva trae como consecuencia que la autonomía privada de los particulares, expresada de manera particular en el 'contrarius consensus', se vea limitada por la realidad del contrato válidamente celebrado y por los efectos típicos que le corresponden, lo cual se traduce en que el contenido del contrato se vuelva inmodificable por la simple voluntad de los particulares en aquellos casos en los que la interpretación del contrato bajo los parámetros de la buena fe así lo indique, hecho desconocido a la luz de la experiencia jurídica contemporánea por virtud de la noción del contrato ${ }^{9 \mathrm{I}}$.

\section{De las otras formas de 'contrarius consensus'}

Hasta este punto se han analizado aquellos supuestos de hecho en los que el 'contrarius consensus' se aplica para eliminar de manera expresa la totalidad del vínculo contractual. No obstante, del análisis de la rica casuística que trata el tema del 'contrarius consensus' en la experiencia romana es posible inferir la validez de otras formas de 'contrarius consensus': los acuerdos tácitos o implícitos dirigidos a

R. CARdilli, Iulianus XV Digestorum (D. I 8,5,5,I-2) e limiti al contrarius consensus, cit., I 55 .

9I En el derecho contemporáneo se afirma el carácter contractual del mutuo disenso por el hecho de que el instituto está encuadrado dentro de la definición del contrato, lo que se traduce en la tesis de que el mutuo disenso es un contrato y por lo tanto, así como las partes celebraron un contrato para establecer una relación jurídica entre ellas, también pueden celebrar otro con la finalidad de extinguir tales relaciones. Bajo esta perspectiva, a la resolución por mutuo consenso se le reconoce absoluta libertad de aplicación. Dos ejemplos a citar: en el derecho colombiano, la jurisprudencia ha entendido que el incumplimiento recíproco de las obligaciones nacidas del contrato bilateral puede interpretarse como un desistimiento mutuo o una conducta concluyente en sentido de destrate, es decir, emplear el 'contrarius consensus' como un correctivo jurídico para aquellas situaciones de incumplimiento y en donde la res integra se desconoce. Ver ConTE Suprema de Justicia de Colombia, Sala de Casación Civil, Sentencia del 23 de septiembre de i974, M.P.: Ernesto Escallón Vargas; F. Hinestrosa, Tratado de las Obligaciones, i, Concepto, estructura, vicisitudes, Bogotá, 2007, 90I. El segundo ejemplo hace referencia a la aplicación del 'contrarius consensus' en aquellos contratos en los cuales hay transferencia del dominio, lo cual lleva a la necesidad de emplear un negocio resolutorio que tenga la facultad de eliminar tales efectos. De esta forma, se discute si la resolución por mutuo consenso tiene la fuerza necesaria de extinguir el vínculo contractual anterior y a su vez retransferir la propiedad (como lo afirman F. Galgano, Degli effetti del contratto, della rappresentanza del contratto per persona da nominare, artt. I372-I405, Roma-Bolonia, I993, I9; P. SirenA, Effetti e vincolo, en Trattato del contratto, diretto da Vicenzo Roppo, III, Milán, 2006, 99; P. CEccHI, L'efficacia del contratto, cit., I8); o, por el contrario, tal figura debe revestir la forma de un 'contra-negocio' (como sostienen R. Scognamiglio, I contratti in generale, en Trattato Grosso-Santoro Passarelli, iv, 2, Milán, I972, 2 Io; F. Caressi, Il contratto, en Trattato di diritto civile e commerciale, diretto da A. Cicu e F. Messineo, xxi, 2, Milán, I987, 873). En el primer caso el 'contrarius consensus' no tiene como fin la transferencia de la propiedad, en el segundo, lo que realmente se hace es usar tipos contractuales como la compraventa, pero denominándolos 'contrarius consensus'. 
la resolución del contrato consensual, y los acuerdos de eliminación parcial de la conventio de las partes, que en últimas son pactos ex intervallo modificatorios del contrato al cual van dirigidos.

\section{I. El 'contrarius consensus' tácito o implícito es una verdadera 'conventio' resolutoria que opera por vía de los actos inequívocos de las partes dirigidos a extinguir el anterior vínculo negocial}

Los juristas clásicos atribuyeron plena eficacia resolutiva ipso iure tanto al 'contrarius consensus' expreso como al acuerdo resolutivo tácito que resulta de actos o de comportamientos concluyentes de las partes. Específicamente, la admisibilidad de esta última clase de acuerdos surge del pacto de las partes tendiente a modificar, rebus adhuc integris, un elemento esencial del contrato como lo es el precio en la compraventa, tal como se expresa en D. I8.I.72 pr. Papinianus Libro х. Quaestionum ${ }^{2}$.

Lo primero que llama la atención del fragmento es la distinción que se hace dentro de la categoría de pacta ex intervallo, pues se afirma que existen pactos celebrados posteriormente a la celebración del contrato que son admitidos dentro del reglamento contractual y otros, por el contrario, que no son admitidos. Esta distinción realizada por Papiniano tiene como fundamento la operatividad del pacto: ya sea porque son pactos que tocan los aspectos del contenido del contrato denominados adminicula emptionis, que en el caso particular es la cautio duplae; ya sea porque tocan elementos del contrato considerados inderogables, denominados substancia ${ }^{93}$, que en el caso particular es el precio de la venta93.

92 D. I 8.r.72 pr. Papinianus Libro x. Quaestionum: "Pacta conventa, quae postea facta detrabunt aliquid emptioni, contineri contractu videntur, quae vero adiiciunt, credimus non inesse. Quod locum habet in bis, quae adminicula sunt emptionis, veluti ne cautio duplae praestetur aut ut cum fideiussore cautio duplae praestetur; sed quo casu agente emtore non valet pactum, idem vires babebit iure exceptionis agente venditore. An ídem dici possit aucto postea vel deminuto pretio, non immerito quaestium est, quoniam emptionis substantia consistit ex pretio. Paulus notat: si ómnibus integris manentibus de augendo vel deminuendo pretio rursum convenit, recessum a priore contractu, et nova emptio intercessiesse videtur" ("Los pactos convenidos, que, hechos después, quitan alguna cosa a la compra, se considera que se contienen en el contrato, pero en lo que la añaden, creemos que no se comprenden. Lo cual tiene lugar respecto de las cosas que son accesorias de la compra, por ejemplo, que no se preste caución del duplo; pero en el caso en que demandando el comprador no sea válido el pacto, tendrá el mismo su fuerza por derecho de excepción, demandando el vendedor. No sin razón se preguntó, si podría decirse lo mismo, habiéndose aumentado o disminuido después el precio, porque el precio consiste en la esencia de la compra. Paulo observa: si estando todo íntegro se convino de nuevo en aumentar o disminuir el precio, se considera que hubo separación del primer contrato, y que medió nueva compra": trad. de García del Corral, Cuerpo del Derecho Civil Romano, Digesto, I, cit., 903).

93 El problema del carácter genuino de la expresión substantia emptionis contenida en el texto fue discutido en el pasado, y se creyó que fue incluida por los compiladores en homenaje a la doctrina bizantina de la natura contractus, si bien la cuestión está superada a favor de la autenticidad. Sobre el particular ver la variada bibliografía que se menciona en R. Fioni, Il problema dell'oggetto del contratto nella tradizione civilistica, en Modelli teorici e metodologici nella 
Esta distinción entre adminicula emptionis y substantia emptionis ${ }^{95}$ se evidencia en la lectura que hace Papiniano de la estructura del contrato. Por una parte, nota que hay aspectos del contenido contractual que determinan la existencia del contrato y por lo tanto su carácter inderogable. Por la otra, afirma que hay elementos cuya ausencia no perjudica la existencia misma del negocio, no son necesarios dentro del contenido contractual y las partes pueden prescindir de ellos $^{96}$. En efecto, el jurista analiza en el fragmento la estructura del contrato de compraventa, y llega a la conclusión de que el precio es un elemento estructural cuya presencia determina la existencia del contrato. En cambio, a la caución la califica como adminiculum emptionis, cuya determinación, aunque integra el contenido contractual, no es determinante para la estructura del contrato y por lo tanto para su existencia.

Por su parte, también se afirma que en la hipótesis de que sea un pacto que trate sobre los adminicula, la admisibilidad dentro del contenido del contrato está limitada a aquellos pactos que simplemente disminuyan el contenido contractual que ya las partes han establecido97.

Por el contrario, cuando el pacto haga referencia a un elemento substantia será admisible pero con efectos claros sobre el contrato: un 'contrarius consensus' tácito y una nova emptio. En otras palabras, los pactos dirigidos a la modificación del contenido inderogable del negocio válidamente celebrado no son considerados simples pactos sino nuevos contratos, en los que se establece, por vía de interpretación, la disolución del primer contrato y la celebración de una compraventa completamente nueva ${ }^{9}$.

Así pues, este análisis permite entender que en aquellos casos en los que las partes celebren un pactum que tenga como fin la modificación de los elementos estructurales del tipo contractual, que para el caso en cuestión es el precio en el contrato de compraventa, sería interpretado como si se estuviese realizando

storia del diritto privato, Nápoles, 2003, I84 n. 56; G. Grosso, Efficacia dei patti nei 'bonae fidei iudicia'. Patti e contratti, cit., Io6; Id., Sistema romano dei contratti, cit., I82.

94 M. Talamanca, La bona fides nei giuristi romani, cit., 88 ss.; R. Cardilli, Il problema della resistenza del tipo contrattuale nel diritto romano tra natura contractus e forma iuris, en Modelli teorici e metodologici nella storia del diritto privato 3, Nápoles, 2008, 44.

95 La distinción que se hace entre substantia y adminicula no debe entenderse de manera generalizada pues se dice que está completamente condicionada dentro del contexto problemático en el cual se formula; sería errado transportarla a la dialéctica general entre pacta conventa y contratos tutelados con los iudicia bonae fidei. Cfr. R. CARdilli, Resistenza del tipo contrattuale nel diritto romano, cit., 46. Para observar tesis contraria, ver B. BIONDI, Iudicia bonae fidei, cit., 34.

96 Fioni, Il problema dell'oggetto del contratto nella tradizione civilistica, cit., I 85.

97 Sobre un análisis de las teorías que interpretan la adición o disminución del contenido del contrato -detrahere aliquid emptione- ver CARDILLI, Resistenza del tipo contrattuale nel diritto romano, cit., 47 y 48.

98 M. Talamanca, La bona fides nei guristi romani, cit., 92; R. CaRdilli, Resistenza del tipo contrattuale nel diritto romano, cit., 44 . 
un 'contrarius consensus' puesto que las partes están incidiendo sobre elementos que identifican el contrato celebrado, y su modificación significaría negar su existencia originaria 99 . Por ello el razonamiento coherente y riguroso del jurista al plantear que tal pacto manifiesta la intención de las partes de separarse de la estructura originaria del contrato para cambiarla por otra ${ }^{\mathrm{I00}}$.

La misma orientación sobre 'contrarius consensus' tácito se encuentra plasmada en el caso de Pomponio en D. i 8.5.2 Pomponius libro XXIV. Ad Sabinum ${ }^{\text {Ior, }}$ en el cual se hace referencia a un contrato de compraventa en el que el precio se aumenta o reduce por acuerdo posterior, siempre y cuando estén sin ejecutar las prestaciones del contrato. Este acuerdo debe ser interpretado como la eliminación de la primera compraventa y la supervivencia de la segunda, además entender a la primera como si jamás hubiese existido. Luego el jurista expresa que tal razonamiento no es posible hacerlo en el caso de que se haya pagado el precio, porque después de pagado el precio no se podrá eliminar el vínculo de dicho contrato.

Así las cosas, el comportamiento de las partes dirigido a aumentar o reducir el precio de una compraventa, elemento característico y estructural del contrato, debe ser interpretado como la resolución convencional de la primera venta y la celebración de una nueva. Por el contrario, el comportamiento de una de las partes dirigido a ejecutar las prestaciones que emanan del contrato significa

99 Otra posición sobre la interpretación del 'contrarius consensus' tácito afirma que en el caso de reducción de las prestaciones principales, los juristas sostenían que el simple hecho de su modificación incidía en el carácter sinalagmático del contrato, por lo cual debía entenderse como un mutuo consenso. No obstante, se presenta el problema de que al mismo tiempo se entiende como un nuevo contrato y por ello le corresponderían las acciones para su tutela, situación que va en contra de la regla ex nudo pacto actio non nascitur. Situación que viene superada por ULPIANo y Pomponio con base en el esquema de reformari contractum y del repeti emptioni. Sobre el particular cfr. Talamanca, La bona fides nei guristi romani, cit., 82 .

ioo Se sostiene que la posición de Papiniano es coherente con su planteamiento, pues decide tomar un esquema en el que identifica la substantia o no de la compraventa para determinar los efectos del pacto ex intervallo, para luego compartir -o superar la duda que tenía- la estructura del renovatus contractus planteado por PAulo. En efecto, este último usaba dicho esquema no solamente en el ámbito de la resolución parcial por mutuo disenso sino también para dar eficacia a un pacto que modifica los elementos esenciales del contrato. M. Talamanca, La bona fides nei guristi romani, cit., 88 y 92. Adicionalmente, con D. I8.r.72 pr. Papiniano confirma que el 'contrarius consensus' tiene efectos ipso iure respecto al contrato, tal como se afirmó anteriormente (ver supra 3·3).

IO I D. I8.5.2 Pomponius libro XXIV ad Sabinum: "Si quam rem a te emi, eandem rursus a te pluris minorisve enero, discessimus a priore emtione; potest enim, dum res integra est, conventione nostra infecta fieri emtio, atque ita consistit posterior emtio, quasi nulla praecesserit. Sed non poterimus eadem ratione uti post pretium solutum infectam emtionem facere non possumus" ("Si la misma cosa que te compré, te la compraré segunda vez por más o por menos, nos separamos de la primera compra; porque es posible mientras está integro el negocio, que por convenio nuestro se anule la compra, y de este modo queda subsistente la compra posterior, como si ninguna le hubiere precedido. Pero no podremos emplear la misma razón hecha la segunda compra después de pagado el precio, porque después de pagado el precio no podemos hacer nula la compra”: trad. de García Del Corral, Cuerpo del Derecho Civil Romano, Digesto, I, cit., 9 I9). 
confirmar lo establecido por las partes en el reglamento negocial, es decir, la intención de extinguir el contrato a causa del cumplimiento de las obligaciones, lo cual genera que no se pueda eliminar el vínculo por voluntad de las partes.

En este sentido, se observa la relación entre D. I 8.5.2 Pomponius libro XXIV. Ad Sabinum y D. г8.r.72 pr. Papinianus Libro X. Quaestionum, y se evidencia la coherencia entre Pomponio y Papiniano respecto a la interpretación que se debe hacer sobre aquellos pactos que van dirigidos a modificar la "esencia" o los elementos que determinan el tipo contractual, en el sentido de entenderse como acuerdos resolutorios tácitos.

\subsection{El llamado 'contrarius consensus' parcial es simplemente un pacto 'ex intervallo' modificatorio}

La doctrina sostiene que las fuentes testifican la figura del 'contrarius consensus' parcial, el cual se concreta bajo la exigibilidad del presupuesto de la res integra, en la reducción -detrabere aliquid contractus- o en la modificación del reglamento negocial -conventio ad imminuendum o ad renovandum- ${ }^{\mathrm{102}}$. No obstante se considera que tal argumentación carece de precisión, puesto que pactos como estos se limitan simplemente a modificar el contrato y no cumplen con la función que tiene el 'contrarius consensus' consistente en la eliminación del fundamento del contrato, esto es, el consensus.

La argumentación sobre la existencia de 'contrarius consensus' parcial está respaldada, por una parte, por las enseñanzas de Juliano y de Pomponio citadas por Ulpiano en D. 2.14.7\$6 Ulpianus libro IV. Ad Edictum ${ }^{\mathrm{IO} 3}$ y, por la otra, por la construcción que hace PAulo en D. 2.14.27\$2. Paulus Libro III ad Edictum.

IO2 Cerami, Risoluzione del contratto, Diritto romano, cit., I 286 ss.; MARINI, Actus contrarius e pacisci nel contrarius consensus, cit., 95 ss.

I03 D. 2.I4.7 $\$ 6$ Ulpianus libro IV ad Edictum: "Adeo autem bonae fidei iudiciis esceptiones postae factae, quae ex eodem sunt contractu, insunt, ut constet in emtione ceterisque bonae fidei iudiciis, re nondum secuta, posse abiri ab emtione. Si igitur in totum potest, cur non et pars eius pactione mutari potest? Et baec ita Pomponius libro sexto ad Edictum scribit: quod quum est, etiam ex parte agentis pactio locum habet, ut et ad actionem proficiat nondum re secuta, eadem ratione; nam si potest tota res tolli, cur non et reformari, ut quodammodo quasi renovatus contractus videatur? Quod non insubtiliter dici potest. Unde illud aeque non reprobo, quod Pomponius libris (libro III) Lectionum probat, posse in parte recedi pacto ab emtione, quasi repetita partis emtione. Sed quum duo beredes emtori extiterunt, venditur cum altero pactus est, ut ab emtione recederetur, ait Iulianus valere pactionem, et dissolvi por parte emtionem; quoniam et ex alio contractu paciscendo alter ex heredibus acquirere sibi potuit exceptionem. Utrumque itaque recte placet, et quod Iulianus, et quod Pomponius" ("Más en tanto se hallan comprendidas en los juicios de buena fe las excepciones hechas después, que son del mismo contrato, como que es sabido que en la compra y en los demás juicios de buena fe, no efectuada todavía la cosa, puede uno separarse de la compra. Si, pues, por un pacto puede cambiarse en su totalidad, ¿por qué no también una parte del mismo? Y así lo escribe Pomponio en el libro sexto de sus Comentarios al Edicto; y siendo esto así, también por la parte del actor tiene lugar el pacto, para que le aproveche también para la acción, no habiéndose verificado todavía la cosa, y esto, por la misma razón; porque si puede revocarse toda la cosa, ¿por qué no también reformarse, para que en cierto modo parezca como renovado el contrato? Lo que no indiscretamente puede decirse. Por 
El fragmento que corresponde a UlPiANo, de basta discusión ${ }^{\mathrm{IO}}$, se plantea la regla de la inherencia de la exceptio pacti a los iudicia bonae fidei, como son, a manera de ejemplo, los pactos celebrados en el contrato de compraventa. El jurista se pregunta: si es posible cambiar la totalidad de este tipo de contratos, ¿por qué no será igualmente posible cambiar solamente una parte del contrato? Sobre esta cuestión, Ulpiano procede a citar a Pomponio quien sostiene que, al ser posible la separación del negocio dentro de los iudicia bonae fidei, el pacto que contiene tal separación le será provechoso al actor y tendrá su respectiva acción, siempre y cuando se conserve íntegro el contrato. Tal posición de Pomponio está justificada por la deducción de que si se puede revocar todo el contrato también es posible revocar solo una parte para que parezca casi renovado el mismo.

En otras palabras, la reconstrucción del pensamiento de PoмPonio en el presente fragmento se puede plantear en los siguientes términos ${ }^{105}$ : (i) la posibilidad de resolver en parte, res integra, el contrato consensual se justifica con base en el mismo criterio que fundamenta la resolución total, esto es, la facultad que tienen las partes de consentire in contrarium; (ii) la resolución parcial no elimina el contrato, sino que va dirigida a modificar algunos elementos no esenciales de manera que aparezca el contrato quasi renovatus (expresión que subraya la imposibilidad de configurar un nuevo contrato, novus contractus, como coherentemente está plasmado en los fragmentos anteriormente citados sobre el particular, D. I8.r.72 pr. Papinianus Libro X. Quaestionum, y D. I8.5.2 Pomponius libro XXIV. Ad Sabinum); (iii) debido a que la conventio parcialmente resolutoria no destruye el contrato en su totalidad, sino que integra el contenido del mismo, los instrumentos que tutelan tal conventio pueden ser eficazmente ejercitados de forma que sirvan para neutralizar las pretensiones que desconozcan lo pactado y al mismo modo componer el reglamento negocial, en virtud de la inherencia de los pacta a los iudicia bonae fidei.

lo cual, con razón no repruebo lo que sostiene Pomponio en sus libros de Lecciones, que por pacto se puede uno separar en parte de la compra, como habiéndose repetido la compra de una parte. Pero cuando quedaron al comprador dos herederos, y el vendedor pactó con uno para que se apartase de la compra, dice Juliano que es válido el pacto, y que se disuelve la compra en aquella parte; porque pactando también en virtud de otro contrato, pudo el otro heredero adquirir para sí la excepción. Así, pues, con razón se admite una y otra cosa, lo que dice Juliano, y lo que Pomponio": trad. de García Del Corral, Cuerpo del Derecho Civil Romano, Digesto, i, cit., 277).

I04 Este fragmento, según Grosso, corre la misma suerte de intervención bizantina consistente en la nivelación y unificación de la buena fe, pues se afirma el principio de exceptio pacti inest bonae fidei iudicis, o pacta conventa insunt bonae fidei iudicis, y por consiguiente se quita la individualidad a cada uno de los pactos. Grosso, Sistema romano dei contratti, cit., I82; Id., Efficacia dei patti nei 'bonae fidei iudicia', cit., 22. Sobre las sospechas de interpolación ver también: B. Biondi, Iudicia bonae fidei, cit., 28 ss. Por otra parte, se afirma que el fragmento tiene evidentes retoques de los compiladres debido a su propósito de evitar en el interior del texto el ius controversium, por ello se puede notar el desorden en la lectura del fragmento. Cfr. Talamanca, La bona fides nei guristi romani, cit., 76 .

io5 Cfr. P. Cerami, Risoluzione del contratto, Diritto romano, cit., I 286 y I 287. 
Como se puede observar en la reconstrucción del planteamiento de РомгоNIo, el fin último del pacto que tiende a resolver en parte el contenido del contrato es modificarlo, mas no cumplir con la función práctica del 'contrarius consensus', consistente en extinguir el vínculo al atacar el consenso que lo fundamenta.

Posteriormente en el fragmento, ULPIANo procede al parecer a reprobar la posición de Pomponio, con base en una opinión de Juliano que demuestra la posibilidad de dissolvi por parte de las obligationes consensu contractae en la aplicación de un caso en concreto: un comprador muere y deja dos herederos, uno de los cuales conviene con el vendedor abire ab emptione -desaparecer la compraventa-, siendo este pacto válido y con plena eficacia para resolver la compra en la parte que corresponda. De manera paralela, el otro heredero está en su derecho de realizar otro pacto con la misma finalidad de disolver su parte de la compraventa y así obtener la excepción que le corresponda ${ }^{\text {I06 }}$.

De la opinión de Juliano es posible inferir que, aunque se está usando los términos dissolvi por parte de las obligationes consensu contractae, el pacto que se celebra por uno de los herederos con el vendedor es en definitiva un pactum de non petendo, puesto que tiene como finalidad eliminar una de las obligaciones de solo uno de los sujetos contratantes en aquellos casos en los que existan obligaciones subjetivamente complejas ${ }^{107}$.

Adicionalmente, la modificación parcial del contrato hecha por Juliano se aparta del modelo de renovari contractum planteado por Pomponio, que no podría ser adoptado en el caso que él cita, ya que el pacto de resolución busca que cada obligación se extinga, y como el otro heredero no participa en tal acuerdo, solo es posible otorgar efectos resolutorios limitados a la parte de la prestación que le corresponde al heredero que celebra el pacto resolutorio. Sería esta última parte la que es acogida por ULPIANo ${ }^{\text {I08 }}$.

En síntesis, de la lectura del texto se desprende que uno de los puntos problemáticos es la modificación parcial del contrato bajo el límite re nondum secuta

Io6 Es de tener en cuenta que este ejemplo de Juliano citado por Ulpiano, D. 2.I 4.7 \$6 libro IV ad Edictum está en completa coherencia con la citación que hace Paulo en los Digesta de Juliano en D. I8.5.4: "si emptio contracta sit, togae puta aut laucis, et pactus sit venditor, ne alterutrus emptio maneat, puto resolvi obligatonem huius rei nomine duntaxat" "Si se hubiera contratado la compra, por ejemplo, de una toga o de una fuente, y el vendedor hubiera pactado que no subsista la compra de una de estas cosas, se considera que se disuelve la obligación solamente respecto de la cosa que se eliminó").

I07 Talamanca, Istituzioni, cit., 642 .

Io8 La expresión de la última parte del fragmento, "Utrumque itaque recte placet, et quod Iulianus, et quod Pomponius", quiere significar que UlPiano acepta alternativamente el modelo de Juliano y el de Pomponio en relación con el problema de la resolución parcial de la compraventa por mutuo disenso, que, como se ha evidenciado, es en definitiva una modificación del contrato. Así, el jurista severiano acoge la argumentación relacionada con el esquema operativo del renovari contractum para todos los casos, salvo en supuestos de hecho específicos como el caso de los herederos, pues existe una posición particular de Juliano consistente en limitar los efectos del pacto. M. Talamanca, La bona fides nei giuristi romani, cit., $86 \mathrm{n} .25 \mathrm{I}$ 
el cual se resuelve afirmativamente bajo la opinión de Pomponio fundamentada en el esquema operativo de la renovari contractus con la modulación de quasi, lo que trae como consecuencia admitir los efectos del pacto sucesivo a la celebración del contrato tendiente a modificar el contenido negocial ${ }^{109}$, siempre que no se busque su sustitución o la eliminación de toda la trama negocial. Así, con la expresión renovatus se podría inducir a creer equivocadamente que con la modificación se haya celebrado un nuevo contrato extintivo-constitutivo; no obstante, el quasi y el videatur referidos en el fragmento hacen la diferencia y corrigen una lectura inadecuada. La verdadera renovación del contrato presupone que las partes hayan querido anular en su totalidad el contrato que fue celebrado y luego realizar un nuevo contrato con un posterior contenido contractual. En cambio, la quasi renovación se refiere a la modificación del contrato ${ }^{\mathrm{IIO}}$, pues el contenido contractual sufre una alteración, transformación o novedad que no se traduce en extinción del vínculo contractual.

La otra fuente que es usada para evidenciar otra forma de 'contrarius consensus' parcial es D. 2.I4.27 $\$ 2$ Paulus Libro III ad Edictum ${ }^{\text {III }}$, en la cual Paulo

Io9 Este esquema de renovari contractus sirve para justificar la regla de ex nudo pacto actio non oritur, pues las partes al modificar el contenido contractual por mutuo consentimiento entienden inequívocamente distrahere parcialmente el negotium, mas no crear un nuevo contrato. Esto se adapta a la interpretación que hacían ULPIANO y PAPINIANo con base en el esquema de reformari contractum. Ver M. Talamanca, La bona fides nei guristi romani, cit., 83 .

I I O R. Marini, Actus contrarius e pacisci nel contrarius consensus, cit., I oo. No obstante, la autora sostiene que la función principal del 'contrarius consensus' es la extinción, total o parcial, de los efectos negociales, y no su modificación. Se afirma que de D. 2.I4.7 $\$ 6$ podría surgir una confusión debido a que al lado de la expresión abiri ab emtione se encuentra pactione mutari, confusión que se supera al sostener que el 'contrarius consensus' tiene una finalidad tanto afirmativa como negativa: el total determina una extinción y una sucesiva constitución de un nuevo vínculo; el parcial, por su lado, lo que hace es empalmar los efectos removidos con los nuevos. Conclusión que no se comparte pues el verdadero 'contrarius consensus' es aquel que cumple la función extintiva de un vínculo consensual, ya sea de manera tácita o de forma expresa, pero siempre cumpliendo con la estructura propia del principio de simetría.

I I I D. 2.I 4.27\$2 Paulus Libro III ad Edictum: "Pactus, ne peteret, postea convenit, ut peteret; prius pactum per posterius elidetur, non quidem ipso iure, sicut tollitur stipulatio per stipulationem, si hoc actum est, quia in stipulationibus ius continetur, in pactis factum versatur; et ideo replicatione exceptio elidetur. Eadem ratione contigit, ne fideiussoribus prius pactum prosit. Sed si pactum conventum tale fuit, quod actionem quoque tolleret, velut iniuriarum, non poterit postea paciscendo, ut agere possit, agere; quia et prima actio sublata est, et posterius pactum ad actionem parandam ineficaz est; non enim ex pacto iniuriarum actio nascitur, sed ex contumelia. Idem dicemus et in bonae fidei contractibus, si pactum conventum totam obligationem sustulerit, veluti emti; non enim ex novo pacto prior obligatio resuscitatur, sed proficiet pactum ad novum contractum. Quiod si non ut totum contractum tolleret, pactum conventum intercessit, sed ut imminueret, posterius pactum potest renovare primum contractum. Quod et in specie dotis actionis procederé potest; puta pactam mulierem, ut praesente die dos redderetur, deinde pacisci, ut tempore ei legibus dato dos deddatur; incipiet dos redire ad ius suum, nec dicendum est, deteriorem conditionem dotis fieri per pactum; quoties enim ad ius, quod lex naturae eius tribuit, de dote actio redit, non fit causa dotis deterior, sed formae suae redditur. Haec et scaevolae nostro placuerunt" ("Habiendo pactado uno que no pediría, convino después en que pediría; el pacto anterior se hace ineficaz por el posterior, no ciertamente de derecho, como se extingue una estipulación por otra estipulación, si esto no ha convenido, porque en las estipulaciones se contiene un derecho, y en los pactos se trata de un hecho; y por ello la excepción hace ineficaz a la réplica. Por la misma razón acontece, que no 
afronta la eficacia modificativa de los pactos ex intervallo en los contratos de buena fe, resaltando, por lo menos a nivel terminológico, el esquema de renovari contractum.

En la primera parte del fragmento se discute el fundamento de hecho del pacto, pues cuando se celebra un pactum de non petendo y a continuación otro posterior que lo extinga, prevalece el posterior, lo cual trae una dialéctica entre exceptio pacti y replicatio. Luego reporta el tema de la eficacia extintiva de una stipulatio por otra, la cual sí tiene su fundamento en el derecho. El discurso posteriormente cita al pactum con eficacia ipso iure sobre la existencia de la obligación, e invoca en un primer momento, como ejemplo, las cuestiones que surgen en el tema de obligationes ex delicto, como lo es la actio iniuriarum, la cual, si se eliminara mediante pacto, después no se podría revivir con otro posterior, puesto que este último pacto es ineficaz para producir la acción por iniuria.

Después se pasa a mencionar los iudicia bona fidei -por lo que parecería inferirse que la primera parte del fragmento que se anotó anteriormente hace referencia a los iudicia stricti iuris-: el supuesto de hecho que se tiene en cuenta en esta parte del fragmento es, por una parte, el pacto de resolución por mutuo consenso de la compraventa, el cual extingue todas las obligaciones del contrato con prestaciones correlativas y, por otra, el alcance de una convención posterior con la que las partes habrían querido eliminar la eficacia del pacto de resolución inicial. Respecto al supuesto de hecho mencionado, se interpreta el pacto posterior como un nuevo contrato y sin efectos de revivir el anterior contrato -non enim ex novo pacto prior obligatio resuscitatur, sed proficiet pactum ad novum contractum-, pues al encontrarse en el ámbito de aplicación de los iudicia bona fidei tal pacto se encuentra admitido.

Es decir, el jurista severiano considera que la primera obligación es extinguida ipso iure por el pacto posterior debido a la inherencia de la exceptio pacti a los iudicia bonae fidei; no es posible regresar a la vida la obligación extinta ${ }^{\mathrm{II}}$; y por

aproveche el primer pacto a los fiadores. Pero si el pacto convenido fue tal que también quitara la acción, como la de injurias, no podrá, pactando después, hacer que pueda reclamar; porque se extinguió la primera acción, y el pacto posterior es ineficaz para producir la acción; pues la acción de injurias no nace de un pacto, sino de una contumelia. Lo mismo diremos también de los contratos de buena fe, si el pacto convenido hubiere anulado toda la obligación, como la de compra; porque por el nuevo pacto no se resucita la anterior obligación, pero aprovechará el pacto para el nuevo contrato. Pero si medió un pacto convenido no para que se anulara todo el contrato, sino para que lo redujera a menos, el pacto posterior puede renovar el primer contrato. Lo que puede ser procedente también en algún caso de la acción de la dote; por ejemplo, si habiendo pactado la mujer que se le devolviese la dote en el día presente, pactare después que la dote le sea devuelta en el tiempo fijado por las leyes; la dote comenzará a volver a su propio derecho, y no ha de decirse que por el pacto se hace peor condición de la dote; porque siempre que la acción de la dote vuelva al derecho que le atribuye la ley de su naturaleza, no se hace peor condición de la dote, sino que se vuelve a su propia forma. Estas cosas parecieron bien también a nuestro Scevola": trad. de García del Corral, Cuerpo del Derecho Civil Romano, Digesto, I, cit., 283).

I 2 Cardilli, Resistenza del tipo contrattuale nel diritto romano, cit., 65. 
último, tal pacto es entendido como un novus contractus. En otras palabras, Paulo tiene presente el principio de ex nudo pacto actio non oritur ${ }^{113}$ y comprende que el pacto ex intervallo de resolución por mutuo consenso tiene efectos ipso iure, cuya interpretación puede orientarse hacia la extinción de las anteriores obligaciones y hacia la celebración de uno nuevo ${ }^{\mathrm{I}} 4$. Hasta este punto el fragmento hace referencia al verdadero 'contrarius consensus'.

Ahora, la llamada resolución parcial de la compraventa por mutuo consenso es referida dentro del fragmento cuando se expresa quiod si non ut totum contractum tolleret, pactum conventum intercessit, sed ut imminueret, posterius pactum potest renovare primum contractum -pero si medió un pacto convenido no para que se anulara todo el contrato, sino para que se lo redujera a menos, el pacto posterior puede renovar el primer contrato-. La situación debe entenderse en conformidad con el punto problemático que se venía tratando: un pacto que tiene como finalidad remover los efectos extintivos de otro anterior que modificaba un vínculo contractual.

En este sentido, Paulo expresa que el pacto posterior a la resolución del contrato puede tener el efecto de renovare primium contractum, sin explicitar los efectos o el modo con el cual debe operar. Por ello, la interpretación respecto a este pacto, conforme al tenor literal del fragmento, indica que el pacto posterior elimina los efectos de un pacto que modificó el contrato y viene a restablecer los efectos iniciales del primer contrato ${ }^{\mathrm{I}}{ }^{\mathrm{5}}$. En este caso, el jurista severiano sigue la construcción del contractus renovatus de Pomponio, el cual es recordado por ULPIANO en D. 2.I4.7 $\$ 6^{[16]}$ y que no busca extinguir la causa de la obligatio, sino la adecuación del contenido negocial a los intereses de las partes. En efecto, aunque el pacto posterior tenga unos efectos extintivos, su función no es la eliminación o sustitución de los elementos estructurales del contrato, sino buscar restablecer los efectos iniciales que el contrato tenía antes de la intervención del primer pacto modificatorio, de manera que permita una renovatio del contrato.

En fin, aunque se afirme que Paulo distingue entre acuerdos resolutivos parciales y totales, el que corresponde a la figura del 'contrarius consensus' es aquel que busca remover el acuerdo de las partes en su totalidad al quitar la estructura

I 3 Talamanca, La bona fides nei guristi romani, cit., 96 .

I 4 Esto se deduce de la concordancia entre las afirmaciones hechas por Papiniano cuando cita a Paulo en D. I8.r.72 pr. y lo que acá se ha dicho de Paulo en D. 2.14.27\$2. En este punto nos parece necesario resaltar la diferencia entre estos fragmentos. D. 2.14.27 $\$ 2$ indica un 'contrarius consensus' expreso pero, por el problema de su cualificación jurídica debido a su contenido, genera que al mismo tiempo sea interpretado como una celebración tácita de un nuevo contrato; situación que no ocurre en D. I8.1.72 pr., pues el pacto que se analiza tiene la finalidad de modificar el contenido contractual de otro contrato, pero debido a que recae sobre elementos esenciales del contrato, en aras de garantizar el carácter sinalagmático y la estructura misma de la obligatio consensus contractae, es interpretada como un 'contrarius consensus' tácito.

I 5 Talamanca, La bona fides nei guristi romani, cit., 98 .

i 6 CARDILli, Resistenza del tipo contrattuale nel diritto romano, cit., 66. 
originaria, no aquel que cumple una función modificadora a fin de adecuar el contrato a las exigencias de la partes.

\section{La esfera de aplicación del 'contrarius consensus' no se limitaba a la resolución del contrato de compraventa, sino que era aplicable a todos los contratos consensuales}

Los fragmentos del Digesto que tratan la resolución por mutuo acuerdo de los contratos consensuales usan como esquema de referencia a la emptio venditio, pues era el contrato más recurrido en la práctica y objeto frecuente de disolución ${ }^{117}$. En general, era el negocio perfecto con el cual no se reducían las estructuras jurídicas a una discusión abstracta sino a su realización en concreto ${ }^{\mathrm{II} 8}$.

Esta última situación, sumada a las teorías interpolacionistas de algunos autores $^{\mathrm{II} 9}$ sobre diversos fragmentos ${ }^{\mathrm{I} 20}$, como el D. 2.I4.58 Neratius libro III. Membranarum, hacen llegar a la conclusión de que el 'contrarius consensus' tenía sentido solo para la resolución del vínculo surgido en el contrato de compraventa y en consecuencia no aplicable a la sociedad, el mandato y el arrendamiento ${ }^{\mathrm{I} 2 \mathrm{I}}$.

Así, en el caso de D. 2.14.58, donde se afirma que "no se duda que por el consentimiento de todos los que entre sí se hubieren obligado sea posible separarse de una compra, venta, locación, conducción, y de las demás obligaciones

I 7 Marini, Actus contrarius e pacisci nel contrarius consensus, cit., I 25 .

i 8 Guarino, Per la storia del 'contrarius consensus', cit., 278.

I I P. Bonfante, Istituzioni di diritto romano, Turín, I946, 426 n. 2; S. Perozzi, Istituzioni di diritto romano, II, Roma, I928, 405 n.4; Id., Il contratto consensuale classico, en Studii giuridici dedicati e offerti a F. Schupfer, I, Turín, I898, I 78; Talamanca, La bona fides nei giuristi romani, cit., Ioo n. 284 .

I 20 Inst. 3.29.4; D. 2.I4.7.\$6 Ulpianus libro IV ad Edictum; D. 46.3.80 Pomponius libro IV ad Quintum Mucium; D. 50.I 7.35 Ulpianus Libro XLVIII ad Sabinum.

I 2 I La problemática del ámbito de aplicación en la doctrina podría sintetizarse en los siguientes términos. Por una parte, Grosso y Siber afirman la disolución de todos los contratos consensuales por vía del 'contrarius consensus', precisando que en el derecho clásico se habría concebido como un actus contrarius con eficacia ipso iure, re adbuc integra, y en la compilación justinianea como un pacta conventa inesse bonae fidei iudiciis. Por otra parte, se desarrolla la tesis de Stoll y Bechmann quienes expresan que el 'contrarius consensus' solamente era aplicable al contrato de compraventa mediante pactum ut babeatur, re adbuc integra; luego los bizantinos usaron el 'contrarius consensus' como un acto contrario que tendría eficacia resolutiva ipso iure con respecto a todos los contratos consensuales. En paralelo a estas dos tendencias están las tesis de GUarino y KNÜTEL: el primero afirma que no existe una importante evolución del clásico al posclásico, pero que se consideraba un medio general de disolución de contratos consensuales; el segundo afirma que el 'contrarius consensus' se movió entre pactum propuesto por Juliano y el actus contrarius propuesto por Paulo, sosteniendo que para el derecho clásico el 'contrarius consensus' no se aplicaba a la sociedad y el mandato, ni tampoco era una expresión del principio de simetría. Cfr. P. Cerami, Risoluzione del contratto, Diritto romano, cit., i $280 ;$ G. Grosso, Recensione a Rolf Knütel, Contrarius consensus, cit., 406; G. Gandolfi, Recensioni critiche a Knütel R. Contrarius consensus, cit., 602; A. Burdese, Recensioni a Rolf Knütel, Contrarius consensus, cit., 343 ss.; G. Grosso, Efficacia dei patti nei 'bonae fidei iudicia', cit., 29 ss. 
semejantes, con tal que todas estén íntegras" ${ }^{\text {222 }}$, las hipótesis de interpolación sostienen que los compiladores decidieron extender la operatividad del 'contrarius consensus' a todos los contratos consensuales debido a su manía teorizante. Ejemplo de ello es que la sentencia de Aristón, citada en el fragmento, solo desarrolla el caso de la compraventa luego de establecer la regla general de resolución consensual de la emptio venditio bajo el límite de la res integra.

La tesis contraria ${ }^{\mathrm{I} 23}$ rechaza las hipótesis tendentes a considerar interpolado el fragmento objeto de ejemplo, pues considera que el requisito que orienta y guía la aplicación del 'contrarius consensus' es la res integra. Entonces, la regla de la extinción del vínculo consensual por 'contrarius consensus' puede ser aplicada a todas las obligationes consensu contractae siempre y cuando ninguna de las prestaciones haya sido ejecutada ${ }^{\mathrm{I} 24}$.

I2 Ab emptione, venditione, locatione, conductione, cesterisque similibus obligationibus, quin integris ómnibus consensu eorum, qui inter se obligati sint, recedi possit, dubium non est.

I 23 Fiori, Bona fides, cit., 234; B. Biond, Iudicia bonae fidei, cit., 23 n. 2; A. Guarino, Per la storia del contrarius consensus, cit., 275; R. MARINI, Actus contrarius e pacisci nel contrarius consensus, cit., I 29; E. Stolfi, Bonae fidei interpretatio, cit., 34 ss.

I 24 En este sentido es necesario entender cómo opera el requisito de res integra en los demás contratos consensuales. En el caso del arrendamiento, que es un contrato de duración, la res integra debía restablecerse con la restitución del bien arrendado en el estado original sin necesidad de restituir los cánones recibidos por parte del arrendador ni compensar el disfrute por parte del arrendatario. De esta manera, la res integra debía analizarse sobre las obligaciones que estaban por ejecutarse y la restitución de la res locata, porque en esta clase de contratos el 'contrarius consensus' no tenía la función de regresar al estado anterior de la ejecución de las prestaciones sino de interrumpir la totalidad de los efectos del contrato, bajo los parámetros que ordena la buena fe. Cfr. R. MARIni, Actus contrarius e pacisci nel contrarius consensus, cit., I 29. Por su parte, el argumento de la inaplicabilidad del 'contrarius consensus' en los contratos de sociedad y mandato está fundamentado en la idea de que la figura usada para la terminación del vínculo consensual en esta clase de contratos era el receso unilateral: ver Cfr. M. TALAmanca, Istituzioni, cit., 643; S. Perozzi, Istituzioni di diritto romano, II, cit., 405 n. 4. Pero las fuentes señalan que la sociedad se disolvía en edad clásica iure civile por 'contrarius consensus', que en el caso en particular se denominaba dissensus sociorum, consistente en una conventio de los socios en la que expresaban el deseo de no continuar vinculados por el hecho de encontrarse en disenso respecto a la sociedad o simplemente dar por terminado el vínculo negocial: sobre el particular, D. I 7.2.65 $\$ 3$ Paulus libro XXXII ad Edictum. En doctrina ver A. Guarino, Dissenus sociorum, en Studi in onore a Volterra, v, Milán, I97 I, I36; Id., Per la storia del contrarius consensus, cit., 275; S. Solazzi, Sul recesso del socio, en IURA, II, I95 I, I 54; M. Talamanca, Società, diritto romano, en ED, XLII, Milán, I990, 844. Con base en esto último, la res integra en el contrato de sociedad era un presupuesto para que los efectos del acuerdo resolutorio surgieran, para lo cual era necesario que las obligaciones que habían nacido fueran liquidadas y luego eliminar aquellas que quedaban por ejecutar. Ver Guarino, Dissenus sociorum, cit., I44.

Por último, en el caso del mandato, el 'contrarius consensus' era aplicable mientras no hubieran tenido principio de ejecución las prestaciones del contrato, es decir, siempre y cuando el mandatario no hubiera dado curso a su encargo teniendo en cuenta los intereses y los derechos de los terceros envueltos en la relación negocial ya sea directa o indirectamente. No obstante no exista fuente expresa sobre el 'contrarius consensus' del mandato, como sí existe para la sociedad, MARINI hace una interpretación sobre G. 3.I 59: "sed recte quoque contractum mandatum, si dum adhuc integra res sit, recovatum fuerit evanescit", coordinado con lo que se expresa en D. I 7.I.I 5 Paulus libro II ad Sabinum: "si mandassem tibi, ut fundum emeres, postea scripssem, ne emeres, tu antequam scias me vetuisse, emisses, mandati tibi obligatus ero, ne dammo adficiatur is qui suscipit 
En efecto, como se ha expuesto, el 'contrarius consensus' surge como una figura llamada a satisfacer la necesidad de extinguir la relación contractual con la base del paralelismo entre el acto constitutivo y el acto extintivo del vínculo negocial, con la condición de que las prestaciones no se hayan ejecutado. Pero tal principio no puede limitarse en su campo de acción al contrato de compraventa por el hecho de ser el único contrato tratado en las fuentes, por el contrario, debe verse como un instituto que al nacer de la praxis negocial es perfectamente aplicable a otros supuestos de hecho siempre que se cumpliera la función de dar por terminado el vínculo de la obligatio consensus contractae bajo el requisito res integra.

\section{El 'contrarius consensus' en la compilación justinianea se ubica dentro del sistema de pactos del derecho romano, como una figura cuya aplicación estaba limitada a la exigibilidad de la 'res integra' como garantía de coherencia del sistema}

El sistema romano de los contratos que sobresale de las fuentes del derecho justinianeo demuestra su carácter preponderantemente típico, pues la obligatio ex contractu solamente podía nacer de la actuación de una serie limitada de figuras típicas reagrupadas en las cuatro categorías re, verbis, litteris, consensu ${ }^{\mathrm{I} 25}$. Al lado de estas figuras típicas existían los contratus innominati, que eran objeto de tutela en aquellos casos en los que subsit causa, es decir, cuando la ejecución de la prestación por una de las partes había generado la obligación del cumplimiento de la contraprestación -D. 2.I4.7 Ulpianus libro IV ad Edictum-, o cuando habían surgido obligaciones para ambas partes: ultro citroque obligationem -D. 50.I6.I9 Ulpiano libro XI ad Edictum-. Entonces, las partes no podían determinar libremente el conjunto de disposiciones de intereses y otorgarles eficacia jurídica, puesto que debían escoger solamente entre los tipos contractuales que el ordenamiento ponía a su disposición, y fuera de tales tipos, el acuerdo tenía eficacia en los casos en que estuviera integrado bajo el esquema de la noción general del contrato de Aristón o Labeón ${ }^{126}$.

mandatum", para llegar a la conclusión de la posibilidad de aplicar el 'contrarius consensus' al mandato, lo cual se comparte. MARINI, Actus contrarius e pacisci nel contrarius consensus, cit., I 39.

I 25 G. Grosso, Il sistema romano dei contratti, cit., I ss.; Id., Contratto, Diritto romano, cit., $75^{2}$ ss.; M. Sargenti, Svolgimento dell'idea di contratto nel pensiero giuridico romano, cit., 28.; M. Talamanca, Contratto e patto nel diritto romano, cit., I 4 ss.; G. AstuTI, I contratti obbligatori nella storia del diritto italiano, I, Milán, 1952, 29 ss.

I 26 Sobre el particular, TALAMANCa considera que la concepción de LABEón es aislada y la concepción de contrato innominado la propone solamente Aristón. El acuerdo fuera de los esquemas típicos puede solo tener eficacia en aquellos casos en los que se cumpla una de las prestaciones. Rechaza además la consideración de que en el derecho romano exista una concepción general del contrato, pues la concepción de LABEón reportada por ULPIANo en D. 50.I6.I9 se refiere al carácter bilateral de los contratos consensuales, caracterizado por el ultro citroque obligari, esto 
Adicionalmente, dentro de la tipicidad del sistema contractual existía una figura de contrato típica por la forma, que se aplicaba a cualquier conjunto de disposiciones particulares: la stipulatio, ya que el esquema de la figura obligatio verborum consistente en la interrogatio-responsio permitía a las partes conseguir los efectos obligatorios que considerasen más oportunos ${ }^{\mathrm{I} 27}$.

Por su parte, las fuentes justinianeas conservan numerosas citas de la contraposición entre contractus y pacta, y stipulatio y pactum, así como del fundamental principio clásico establecido en D. 2.14.7\$4 Ulpiano libro IV ad Edictum y según el cual cum nulla subest causa, propter conventionem constat non posse constitui obligationem: agitur nuda pactio obligationem non parit -cuando no subsiste causa alguna, es sabido que por la convención no se constituye obligación: por lo tanto, el nudo pacto no produce obligación-. Tales citas ponen de presente, por una parte, que el nudo pacto, a diferencia de la stipulatio, no era capaz de producir un vínculo obligatorio al carecer de causa en sentido material; por la otra, la ineficacia del pacto debido a su carencia de una causa típica reconocida por el ordenamiento, lo que lo distingue del contractus ${ }^{\mathrm{I} 28}$. Adicionalmente, dentro de esas citaciones se evidencia que el sistema contractual se fundaba sobre categorías dogmáticas tradicionales y figuras concretas cuyo elemento central era la creación de un vínculo obligatorio entre las partes provisto de una eficacia y una tutela específica por el ordenamiento jurídico.

Teniendo en cuenta esta descripción del sistema contractual romano, el 'contrarius consensus' se ubicaba como una forma de pacto y jamás como un tipo contractual, como sí acontece en las codificaciones contemporáneas. Las partes, mediante un simple acuerdo, decidían dar por terminada una relación contractual preexistente pero sin la producción de un vínculo contractual, puesto que su querer iba dirigido a la extinción de la relación obligacional y no a producir nuevas obligaciones. Además, la exigencia del requisito de la res integra como elemento estructural del 'contrarius consensus' permitía que la figura no fuese en contra de las estructuras dogmáticas elaboradas dentro del sistema contractual, ya que de aceptar la operatividad del 'contrarius consensus' luego de ejecutadas

es, por la contemporánea asunción de obligaciones por parte de los contrayentes, teniendo en cuenta que tal bilateralidad es de carácter objetivo: M. Talamanca, Istituzioni, cit., 534 y 537. Sobre la definición del contrato según Labeón ver Gallo, Synallagma e conventio nel contratto, cit., 3 ss.

I 27 No obstante, debe tenerse en cuenta que para la tradición romanista posterior a la compilación justinianea, la stipulatio se caracterizaba por su forma documental, en la que igualmente se podía insertar cualquier contenido negocial, debido a que conservaba su carácter abstracto aunque hubiese perdido su forma. Cfr. Biondi, Contratto e stipulatio, cit., p. 29I; Astuti, I contratti obbligatori, cit., 85 ss.

I 28 G. Astuti, I contratti obligatori, cit., I 70 ss.; Id., Il contratto, diritto intermedio, en ED, IX, Milán, I989, 762; B. Biondi, Contratto e stipulatio, cit., I 24 y I 78 ss., M. TAlamanca, Contratto e patto nel diritto romano, cit., 32; G. Diósdi, Pacta nuda servabo?, cit., 90 ss.; P. Bonfante, Sul 'contractus', e sui 'pacta', cit., I 35 ss. 
las prestaciones, quedaría la causa de la obligación y por lo tanto la obligación sería repetible, lo que conduciría a no extinguir el vínculo de las partes y dejarlo desequilibrado para alguna de ellas.

Todas estas construcciones romanas se elaboraron a partir de la inmediación empírica y el análisis de las figuras mediante un método casuístico. Se estudiaba cuidadosamente la celebración del contrato por el simple consenso, y junto a ello su opuesto, la visión concreta de la resolución por el simple consentimiento. Por ello no se trataba simplemente de la preocupación práctica de que de un pacto no podía nacer una acción, sino que se buscaba dar importancia a la coherencia del sistema y al respeto de las figuras dogmáticas, que en definitiva se traduce en la consideración de los postulados que la buena fe ordena dentro de las relaciones negociales.

\section{Bibliografía}

Astuti, I contratti obbligatori nella storia del diritto italiano, I, Milán, I952.

Astuti, Il contratto, diritto intermedio, en ED, Ix, Milán, I989.

Betti, Teoria generale del negozio giuridico, Nápoles, 2002.

Bianca, Diritto civile, iII, Il contratto, Milán, i987.

Bianca, Il diritto romano nella formazione del giurista, oggi: considerazioni di un civilista, en Il diritto romano nella formazione del giurista, oggi. Convegno organizzato dalla Facoltà di giurisprudenza della seconda Università di Roma, Milán, I989.

Biondi, Iudicia bonae fidei, en Annali del Seminario Giuridico, Università di Palermo, vir, Palermo, i9i 8.

Biondi, Contratto e stipulatio, Milán, I953.

Bonfante, Corso de diritto romano, Florencia, I900.

Bonfante, Sul 'contractus' e sui 'pacta', en Scritti giuridici varii, III, Turín, I92 I.

Bonfante, Istituzioni di diritto romano, Torino, 1946.

Burdese, Manuale di diritto privato romano, Turín, I993.

Burdese. Recensioni a Rolf Knütel, 'Contrarius consensus, Studien zur Vertragsanfhebung im romischen Recht', en INDEX, 2, Nápoles, I97 I. 
Cancelli, Dissenso, profilo storico, en ED, XIII, Milán, I989.

Cannata, La 'distinctio' re-verbis-litteris-consensu et les problèmes de la pratique (Études sur les obligations I), en Sein und Werden im Recht Festgabe U. von Lübtow, Berlín, I970.

Cardilli, Bona fides tra storia e sistema, Turín, 20 Io.

Cardilli, Societas vitae. Cic. Off. 3.I 7.7o e obligatio consensu contracta, en $B u$ llettino dell'Istituto di Diritto romano 'Vittorio Scialoja', Milán, 20 I I.

CARDILli, Il problema della resistenza del tipo contrattuale nel diritto romano tra natura contractus e forma iuris, en Modelli teorici e metodologici nella storia del diritto privato 3, Nápoles, 2008.

CARDIlli, Iulianus xv Digestorum (D. I 8,5,5,I-2) e limiti al contrarius consensus, en Sonderbruck aus Festschrift für Rolf Knütel zum 7o. Geburtstag, Heidelberg, 2012.

Caressi, Il contratto, en Trattato di diritto civile e commerciale, diretto da A. Cicu e F. Messineo, xxi, 2, Milán, I987.

Cascione, Consensus, problema di origine, tutela processuale, prospettive sistematiche, Nápoles, 2003.

Cecchi, L'efficacia del contratto, en I contratti in generale, viII, en Il Diritto privato nella giurisprudenza, a cura di Paolo Cendon, Turín, I998.

Cerami, Risoluzioni del contratto, Diritto romano, en ED, xI, Milán, I989.

Costa. L'exceptio doli, Roma, I970.

Cherubini, Degli effetti del contratto, en Dei contratti in generale, artt. 1350 e 1386 , en Commentario del codice civile, a cura da Enrico Gabrielli, Turín, 2008.

D'Angelo, Il contratto in generale, Iv, La buona fede, en Tratatto di diritto privato, diretto da M. Bessone, xIII, Turín, 2004.

De Martino. Le garanzie personali dell'obbligazione, I, Roma, I940.

Deiana, Contrarius consensus, en Rivista di diritto privato, I939. 
Diosdi, 'Pacta nuda servabo? Nuovi dubbi intorno ad un vechio problema', en Bullettino dell'Instituto di diritto romano, Milán, I97 I.

Fiori, 'Bona fides, formazione, esecuzione e interpretazione del contratto nella tradizione civilistica', en Modelli teorici e metodologici nella storia del diritto privatto, 4, Nápoles, 2 O I.

FIori, 'Contrahere e solvere obligationem in Q. Mucio Scevola', en Fides Humanitas Ius. Studi in onore di Luigi Labruna, Nápoles, 2007.

FIORI, Il problema dell'oggetto del contratto nella tradizione civilistica', en $M o-$ delli teorici e metodologici nella storia del diritto privato, Nápoles, 2003.

Franzoni, Degli effetti del contratto en Il Codice Civile Commentario diretto da Piero Schlesinger, artt.1372-1373, I, Milán, I 998.

Franzoni, Mutuo dissenso, en Enciclopedia Giuridica, Roma, 2004.

Frezza, Le garanzie delle obbligazioni, Corso di Diritto Romano, I, Padova, I 962.

Frezza, 'Fides Bona', en Studi sulla buona fede, Milán, I975.

Galgano, Trattato di diritto civile, II, Milán, 2009.

Gallo, 'Synallagma e conventio nel contratto, ricerca degli archetipi della categoria contrattuale e spunti per la revisione di impostazioni moderne'. Corso di Diritto romano, I, Turín, I992.

Gandolfi. "Recensioni critiche a Knütel, R. 'Contrarius consensus, Studien zur Vertragsaufhebung im römischem Recht'”, en IURA, 20, Nápoles, I969.

Ganzzoni, Obbligazione e contratti, Nápoles, 2000.

Grosso, Il sistema romano dei contratti, Turín, I963.

Grosso, Contratto (diritto romano), en ED IX, Milán, I989.

Grosso, "L'efficacia dei patti nei 'bonae fidei iudicia'”, en Scritti storico giuridici, III, Turín, 200 I.

Grosso, "L'efficacia dei patti nei 'bonae fidei iudicia'. Patti e contratti”, en Studi storico giuridici, III, Turín, $200 \mathrm{I}$. 
Grosso. "Recensione a Rolf Knütel, 'Contrarius consensus, Studien zur Vertragsanfhebung im romischen Recht'”, en Studia et Documenta Historiae et Iuris, 34, I968.

Grosso, La concepción del contrato en el derecho romano y su influencia en los derechos modernos, en Roma e America. Diritto romano comune, 7, Roma, I999.

Guarino. "Per la storia del 'contrarius consensus", en LABEO, Nápoles, i968.

Guarino, 'Dissensus sociorum', en Studi in onore a Volterra, v, Milán, I97 I.

Hinestrosa, Leyendo el Digesto, en Roma e America. Diritto romano comune, 22, Roma, 2006.

Hinestrosa, Tratado de las obligaciones, i, Concepto, estructura y vicisitudes, Bogotá, 2007.

Hinestrosa, Función, límites y cargas de la autonomía privada, en Estudios de derecho privado, Universidad Externado de Colombia, Bogotá, I986.

Hinestrosa, Eficacia e ineficacia del contrato, en Revista de Derecho de la Universidad Católica Valparaíso, Chile, I999.

Luminoso, Il mutuo dissenso, Milán, I980.

Lenel, 'Palingenesia iuris civilis'. Volumen primus, Austria, I960.

Mannino, L'estensione al garante delle eccezioni del debitore principale nel diritto romano classico, Turín, I992.

Marini. 'Actus contrarius e pacisci nel contrarius consensus', tesis de doctorado, Università degli studi di Roma 'Tor Vergata', Roma, 20 Io.

Messineo, Dissenso, diritto civile, en ED, XII, Milán, I989.

Milone, 'La exceptio doli (generalis), Studio di diritto romano', Roma, I970.

Neme Villarreal, La buena fe en el derecho romano. Extensión del deber de actuar conforme a buena fe en materia contractual, Bogotá, 2010.

Periñán, Pomponio y la clasificación de los modos de extinción de las obligaciones, en IURA, LII, Nápoles, 200 I. 
Perozzi, Istituzioni di diritto romano, II, Roma, I928.

Perozzi, Il contratto consensuale classico, en Studii giuridici dedicati e offerti a F. Schupfer, I, Turín, I 898.

Roppo, Il contratto, Milán, 20 I I.

SARgenti, Svolgimento dell'idea di contratto nel pensiero giuridico romano, en IURA, 39, I988.

Schipani, 'Iustiniani Augusti Digesta seu Pandectae', Testo e traduzione, Milán, 2005.

Scognamiglio, I contratti in generale, en Trattato Grosso-Santoro Passarelli, IV, 2, Milán, 1972.

Sirena, Effetti e vincolo, en Trattato del contratto, diretto da Vicenzo Roppo, III, coordinato da M. Constanza, Milán, 2006.

Solazzi, L'estinzione dell'obligazione nel diritto romano, I, Nápoles, I935.

Solazzi, Sul recesso del socio, en IURA, II, I95 I.

Stolfi, 'Bonae fidei interpretatio. Ricerche sull'interpretazione di buona fede fra esperienza romana e tradizione romanistica', Nápoles, 2004.

Talamanca, 'La bona fides nei giuristi romani: 'Leerformeln' e valori dell'ordinemento', en Il ruolo della buona fe oggettiva nell'esperienza giuridica storica e contemporanea, a cura di L. Garofalo, Iv, Turín, 2003.

Talamanca, Istituzioni di Diritto romano, Milán, I990.

Talamanca, Contratto e patto nel diritto romano, en Estratto dal Digesto, Turín, i 989.

Talamanca, Società, diritto romano, en ED, XLII, Milán, I990.

Voci, La dottrina romana del contratto, Milán, I946. 